Historic, archived document

Do not assume content reflects current scientific knowledge, policies, or practices. 



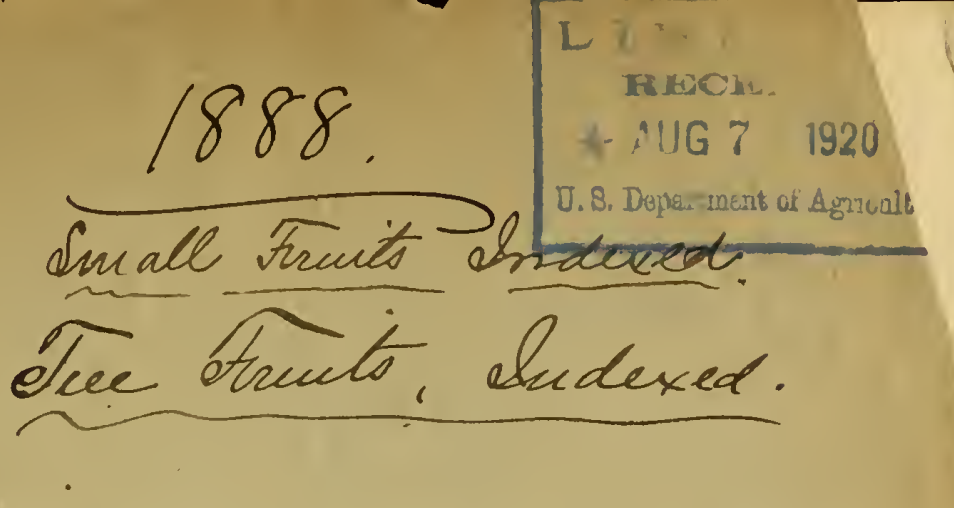

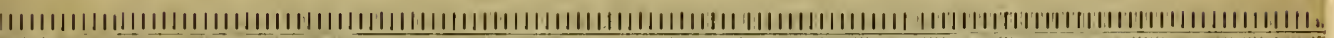

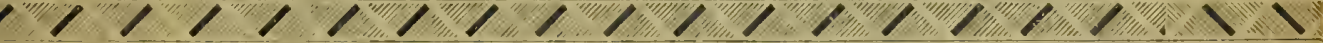

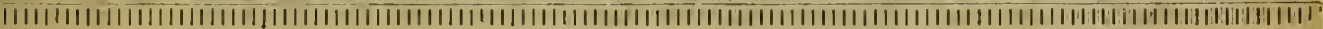

\section{$\rightarrow$ CATALOGUE:}

$-\mathrm{OF}-$

Fruit on Ornamental Grees,

Vines, Shrubbery, Roses, \&c.,

CILTVATEW IXD FOR SALF AT THF:

Morris Nurseries,

WEST CHESTER, PA.

George Achelis, Proprietor.

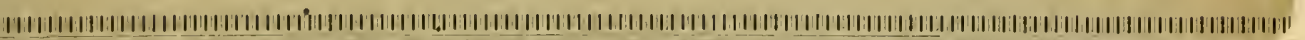

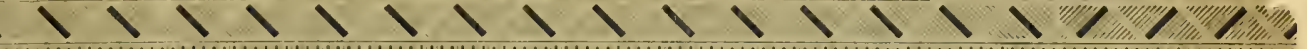

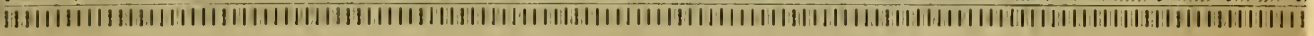




\section{- INDEX.}

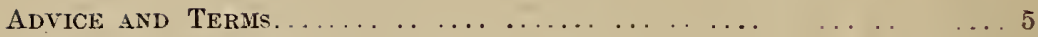

A.PPLES . . . . . . . . . . . . . . . . . . . . . . . . 7

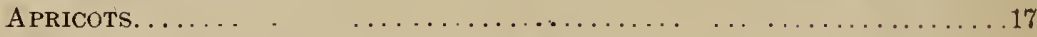

BLACKBERRIES. . . . . . . . . . . . . . . . . . . . . . . . . 10

Brief Directions for Transplanting, Etc.............. 5

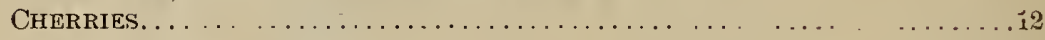

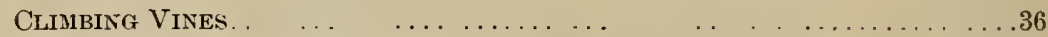

Crab apples........... $\ldots \ldots \ldots \ldots 10$

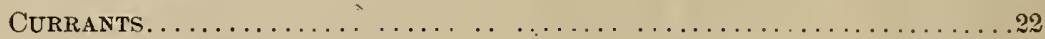

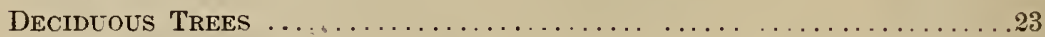

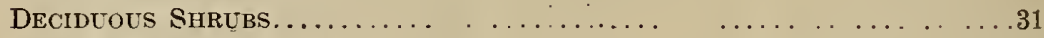

Distance for Planting. ............................. 5

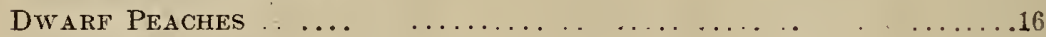

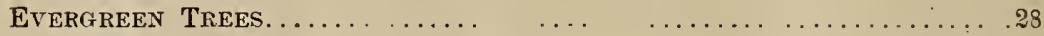

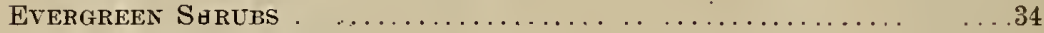

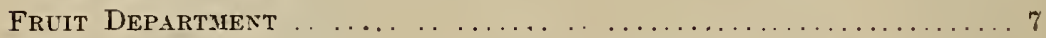

GooseberRIES $\ldots \ldots \ldots \ldots \ldots \ldots \ldots \ldots \ldots \ldots$

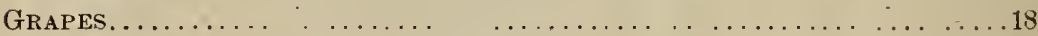

Hedge Plants. . . . . . . . . . . . . . . . . . . . . . . . . 37

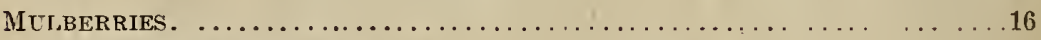

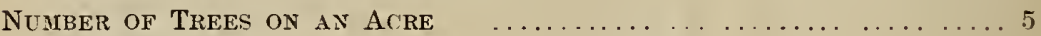

NECTARINES. . . . . . . . . . . . . . . . . . . . . . . . . . . . 18

Nuts. . . . . . . . . . . . . . . . . . . . . . . . . . 18

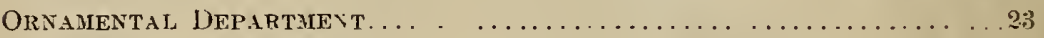

Peaches... . . . . . . . . . . . . . . . . . . . 14

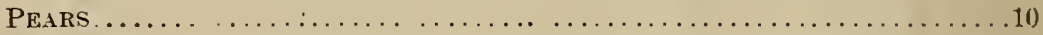

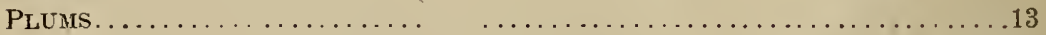

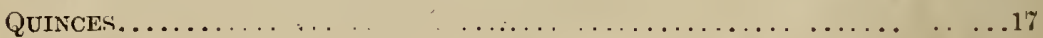

RASPBERRIES.... . . . . . . . . . . . . . . . . . . . ?

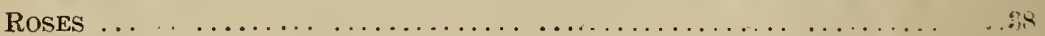

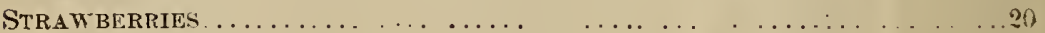





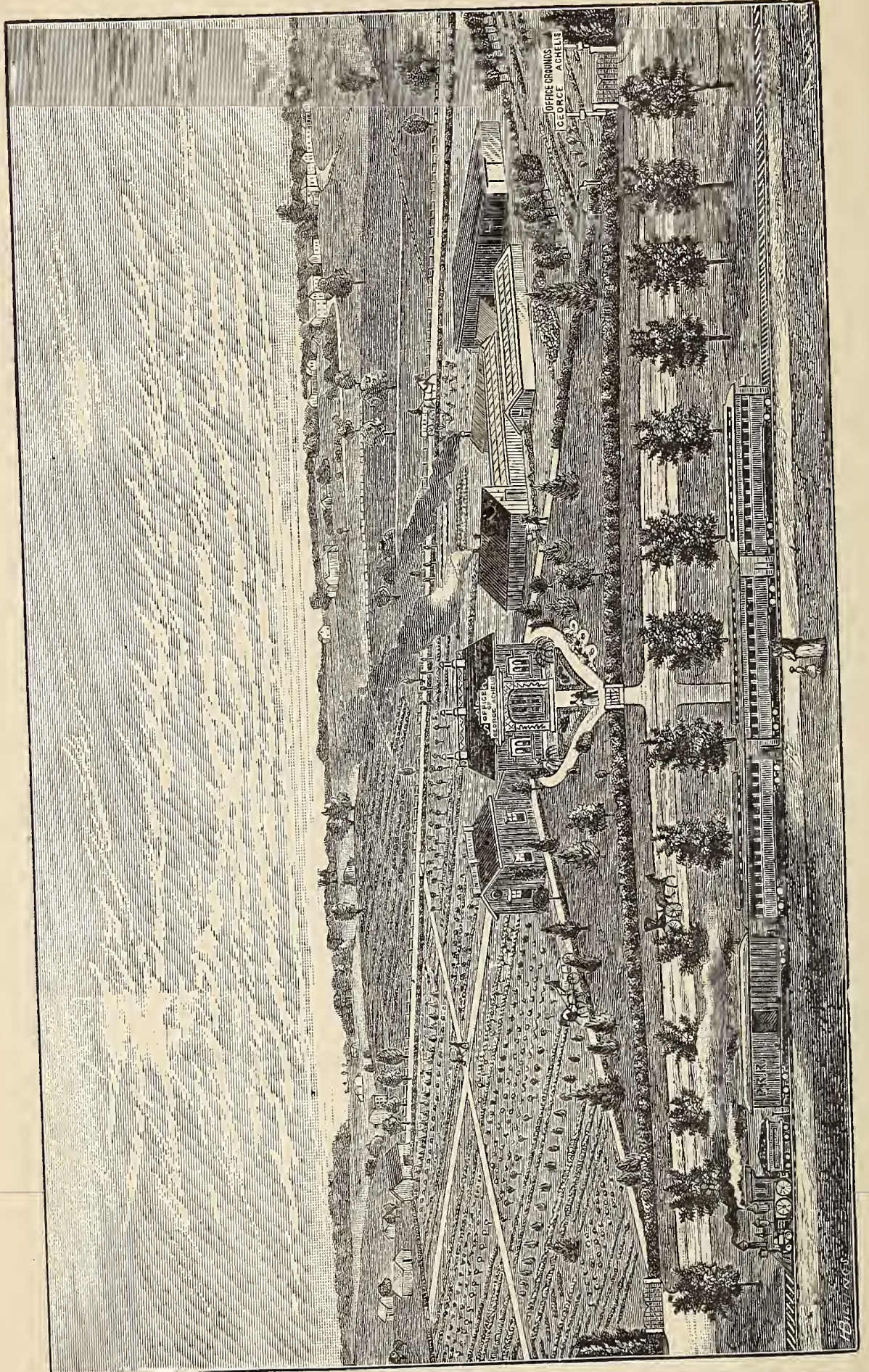




\title{
CATALOGUE:
}

$-\mathrm{OF}-$

\section{Frult and Ornamental Trees,}

$\varangle$ Shrubbery, Vines, Roses, \& $\&$

\author{
CL'LTIVATED AND FOR SALE AT THE
}

\section{Morris Nurseries,}

WEST CHESTER, PA.

GEORGE ACHELIS, PROPRIETOR.

ROCHESTER, N. Y., Union and Advertisek Co., Printers and Plblishers, 188 . 
.

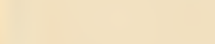

(1) 


\section{USEFUL INFORMATION.}

\section{DISTANCES FOR PLANTING.}

Standard Apples............................................

Stand ard Pears, and stroug growing Cherries............20

Duke and Morello Cherries.............................. 18

Standard Plums, Peaches, Apricots, Nectarines......12 to 18

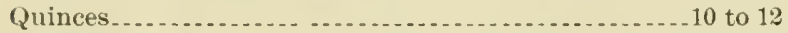

Dwarf Apples................................... 8

Iwarf Cherries and Dwarf Pears.................... 8 to 12

Currants, Gooseberries and, Strawberries............ 3 to 4

Blackberries .........

$\begin{array}{ll}\text { " } & \text { "6 } \\ \text { " } & \text { " } \\ \text { " } & \text { " } \\ \text { " } & \text { " }\end{array}$

\section{NUMBER OF TREES ON AN ACRE, WHEN PLANTED AT STATED DISTANCES.}

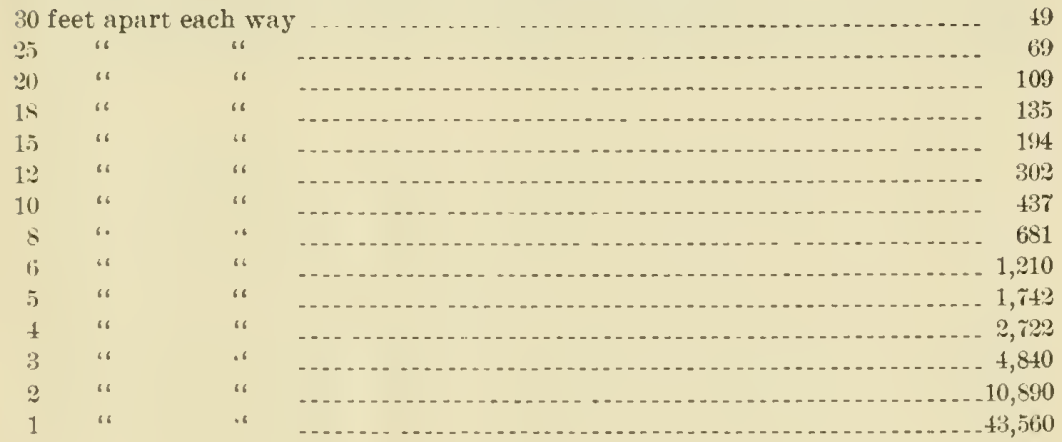

\section{ADVICE AND TERMS.}

To avoid mistakes, write the order plainly, and state whether Standard or Dwarf Fruit Trees are wanted. A moderate charge is made for packing, sufficient to remunerate for time and cost of material. Let explicit shipping directions accompany the order.

All articles are at the risk of the purchaser after being delivered to the Railroad Company or any other forwarder.

TERM: : Cash with order, or satisfactory reference.

\section{BRIEF DIRECTIONS FOR TRANSPLANTING TREES AND PLANTS, AND FOR THEIR SUBSEQUENT CULTURE.}

I'repare the ground as for a crop of corn: then dig the holes just large enough to admit the roots, without crowding and doubling them up. Avoid deep planting, which is decidedly injurious to the tree, and when excessive may cause its death. It should be no deeper than it stood before removal from the Nursery. A mound of earth, one foot high, should be heeled up around the trees when planted in the Fall-it makes them firmer to withstand the Winter and is a protection to the roots. It should be leveled again in the spring. 
Before planting, the injured parts of the roots should be cut off smoothly with a sharp knife.

Shortening the branches is another very important matter to the life and vigor of the tree, and should be done at the time of planting. It consists in cutting back the ends of the branches, but to what extent it should be done depends upon circumstances. If a tree has lost the greater portion of its roots, a severe shortening in of the head will be necessary; if only a small portion of the roots are cut off, moderate pruning will be sufficient. In all cases it should be done in a manner corresponding with the loss of roots.

Cultivate the orchard a few years with hoed crops. To insure regular crops of fruit, an orchard should be kept afterwards permanently in sod, and manure applied to the surface.

Dwarf Pears should be planted so as to cover about one inch above the graft. Cut back about one-third of the last year's growth every year. All dwarf fruit trees should receive high cultivation, and be kept clear of grass and weeds.

Small fruits, such as Raspberries, Blackberries, etc., should be cut down close to the ground, and not allowed to fruit the first year.

The best time for planting evergreens is end of October or commencement of November. The wood is then well ripened and can stand the severity of the winter; the plants are ready to start growing when the spring opens, and are not as liable to suffer by early summer droughts as evergreens which are planted in the spring. And lastly, when packed in boxes for shipment, they are not as liable to heat in the late fall as in the spring, when the weather begins to get warm. 


\section{FRUIT DEPARTMENT.}

\section{APPLES.}

The following varieties have been well tested and can be recommended. The selection of varieties ought to be governed by the climate and soil of the planter, as it is well known tnat several good New Fork varieties do not prove profitable for Pinnsylurniu, etc.

\section{SUMMER VARIETIES.}

Bough. Large; pale greenish yellow; sweet, rich flavor; good bearer. First of August.

$\checkmark$ Carolina Red June. Fruit medium size; skin smooth, shaded with doep red. Flesh white, tender, juicy, with sub-acid flavor; very good and productive. August.

Early Strawberry. Medium size; yellowish white, striped with red ; tender, mild, fine flavor: good bearer. August.

Early Harvest. Medium size, pale yellow; rich, sub-acid flavor; very producrive. Commencement of August.

Early Ripe. Supposed Penusylvania origin; productive; pale yellow, sprinkled with a few gray dots. Flesh white, tender, juicy, sub-acid; good. August.

Colden Sweet. Rather large, pale yellow; very sweet and good; good bearer August.

Keswick Codlin. I arge, tender, juicy, acid; excellent for cooking; productive and early bearer. July to October.

Red Astrachan. Rather large; deep crimson with a pale white bloom juicy, acid Havor; productive. August.

Summer Rambo. Medium to large; green, striped with red; sub-acid, goorl. Good market apple. September.

Tetofsky. A Russian apple which proves profitable for market, comes early into bearing, and produces annually. Very hardy ; fruit round and smooth, with yellow ground handsomely striped with red. Flesh white and juicy. August.

Yellow Transparent. A new Russian variety, ripening a week or two before Tetofsky. Skin, when fully ripe, pale yellow; flesh tender, juicy, lively sub-acid.

\section{FALL VARIETIES.}

Alexander. Very large; crimson striped, juicy. Quality and productiveness fair. A Russian apple. October.

Duchesse of Oldenburgh. Medium: yellow, striped with red; rich, juicy and excellent: a productive variety introduced from Russia. September.

Fall Jenneting. Large, greenish-yellow; sub-acid, vigorous and productive. September and October.

Fall Pippin. Very large; yellow, rich, high flavored; moderate bearer. October to Nnvember.

Fall Strawberry. Medium; yellow, striped with red; juicy, sub-acid; excellent, productive. September and October.

Gravenstein. Very large; red striped, first quality; very productive. September and Octoher.

Haas, or Fall Queen. Medium, striped with red. Flesh white, juicy, acid, rich, very good.

/ Hays. (Pennsylvanin led streak or Wine). Fruit above medium size: skin smooth, deep red with inclistinct lines of yellow; flesh yellowish white, juicy, crisp, rich and pleasant flavor. October to March.

Jefferis. Medium; yellow, shaded and splashed with crimson and covered with large white dots : mild, very good. September.

Jersey Sweeting. Medium; striped red and green: tender, juicy and sweet. Sieptember to (ctober. 
Lowell. Tree hardy and a vigorous grower. Fruit large, bright waxen yellow: flesh yellowish white, with a rich, rather acid flavor. September to October.

Maiden's Blush. Rather large; pale yellow with red cheek; beautiful, valuable for market; abundant bearer. September to October.

Porter. Fruit large; clear bright yellow; fine grained and juicy, agreeable sub-acid; very good to best. Ripens in September.

Rambo. Medium; flat, streaked and marbled with yellow; very tender, rich, sub-acid flavor; good bearer. October to December.

Red Bietigheimer. Very large, light yellow, covered with red, purplish crimson when exposed to the sun ; flesh sub-acid, pleasant; a great bearer. September.

\section{WINTER VARIETIES.}

Valdwin. Well known; large, bright red; juicy and rich; productive. December to March.

Ben Davis. (New York Pipin). Large, striped with bright red; juicy, sub-acid, good. Much esteemed in the West and South. December to March.

Belleflower. Yellow ; large ; crisp and juicy, aromatic flavor ; moderately productive. November to March.

Belmont. Pennsylvania origin; healthy and very productive. Fruit medium to lurge, light waxen yellow with a bright vermillion cheek; flesh yellowish, crisp, tender, juicy and of agreeable flavor. November to February.

$\checkmark$ Bullock Pippin, or Ewalt. A Pennsylvania apple; large, bright yellow, with shades of crimson in the sun ; white, tender flesh, sub-acid ; first quality: A good keeper. November to March.

Cider, Smith's. Popular Pennsylvania fruit; greenish white, striped with red; juicy, tender, mild, pleasant flavor; very productive, good keeper. December to March.

Cooper's Market. (Choper's Redling). Medium size; yellowish, shaded with red and striped with crimson; wh ite and tender flesh, sub-acid ; very productive and a late keeper. December to May.

$\checkmark$ Delaware Winter. Originated in Delaware. Remarkable for its keeping qualities. Fruit medium to large, highly colored; flesh fine grained, juicy, crisp, excellent. Prolific, and commences to bear early.

Dickinson. From seed of the Bellefleur. Medium to large, yellow, almost covered with faint red streaks; mild, sub-acid, very juicy. A prolific and regular bearer. January to March.

Domine. Medium; white flesh, tender, juicy, pleasant flavor; very productive, excellent keeper. December to April.

Fallawater. Favorite Pennsylvania fruit. Very large, vellowish-green ; valuable market variety. Very productive. November to February.

Fameuse, or Snow Apple. Medium size; very handsome, deep crimson; tender, white fleshed, juicy, high flavored; productive. November to December.

Grimes' Golden. Medium, rich golden yellow; crisp, tender. juicy ; does well in Pennsylvania. Early bearer and excellent keeper. January to April.

Hubbardston Nonsuch. Large; yellowish ground with red stripes and spots; sweet and rich. Highly esteemed. November to January.

Krauser. Berks Co., Pa., fruit; medium, yellow; handsome appearance and a good keeper. December to April.

$\checkmark$ King of Tompkins Co. Large ; yellow, striped with red; popular variety, good bearer. December to March.

Ladies' Sweeting. Medium; yellow, striped with red; rich and juicy, high flavor; good bearer. December to March.

Lady. Fruit small but regular; skin smooth and glossy with a deep red cheek; flesh white, crisp, tender and juicy; brings the highest price of any fancy apple in the market. Hardy and productive. December to May.

Lankford Seedlingi A fine showy apple; medium to large; yellow, striped, near!y covered with bright red. Flesh firm, juicy, mild, sub-acid. One of the best late keepers. January to May.

Mann. Fruit resembles R. I. Greening, but is larger. Tree hardy, comes into bearing young, and loads itself about every year with large crops. February to Jinne.

Mclntosh Red. Originated in Canada. Above medium size. Yellow nearly covered with dark rich crimson. Flesh white, tender, juicy. Tree very hardy ; good bearer of excellent fruit. November to April. 
Monmouth Pippin. Nuit large: color yellow, with russet dots; juicy, fine sulb-acid. Very good to best. October to November.

Newtown Pippin. Rather above medium size; excellent flavor. December to Jay. A vely pon growel.

Nickajack. Large, striped: fair quality, hardy, productive and a good keeper. A southern variety. December to April.

Northern Spy. large: striped and covered with dark crimson; a New Tork fruit; juicy, hich flavor, great bearer. January to May.

Peck's Pleasant. large, vellow with lolusli cheek: fine flavor: a good substitute for Newton ['ippin: good bearer and keeper. Novenber to April.

Pennock. Pennsylvania origin : frnit quite large: flesh yellow, tender, and juicy, with a pleasaint half sweet flavor; sood. November to March.

Pewaukee. Jlarly and productive: frnit medium to large; skin bright rellow, strijed and mettled with light and lark: flesh white, juicy, sub-acid, goon. Januily to May.

Pyle's Red Winter. A chance seedling, o'igrinaterl in Clester Co., P'a. Of great value as a market variety, being larue and showy, of good guality and a good keeper. Fruit large: pale yellow, shaded with red: flesh whitish yellow, crisp, tender, juicy, pleasint, lively sub-acid. Jauuary to March.

Rawle's Janet. (Nerer Fril.) Taluable, of Southern origin: medium ; yellow, striper with led ; crisp, rich and jnicy : very productive and a goorl keeper. January to May.

Red Romanite. (Gilpin of Crothouse) Medium ; dark red, white flesh ; crisp sulb-acill, makes good cider: late keeper, very prodnctive. Feb. to May.

Rhode Island Greening. Well known, excellent valiety; large, light greenisly yellow: firm and rich, excellent flavor : crooked grower, good keeper aud goorl bearer. November to March.

Rome Beauty. Iarge: striped with bright red; flesh tender, juicy, sprightly: molerate grower. Origin Ohio. December to February.

Russett. American Colden. ishcep Nose.) Below medium; dull yellow: yellow flesh, very tender, rich spicy flavor; a great bearer and good keeper. December to March.

Russett. English. Medium: pale yellow; fim and crisp, mild sub-rcid flayor, late keejer; rery productive, keeps till June.

Roxbury Russett. Medimm size: skin at first dull green, covered with brownish yellow russet when ripe: flesh greenish white, moderately juicy, with lich sul) acid favor: good to very good. January to Jume.

Salume. Fruit medium ; pale yellow, sliglitly shaded with pale red, splashed and striped with dark red, and sprinkled with small yellow dots; flesh tender, juicy, mild snb-acid. Comes into bearing early. Tery hardy. January to June. Anexiellent kerper.

Smokehouse. Popular Pennsylvania fruit, and valued highly; above mediun : yellow, sharled with bright red, sprinkled with gray and brown dots; firm, juicr, sub-acid flaror: good hearer. November t a February.

Spitzenburgh. (Ksmpus.) Frnit large, considered eçual to Newtown l'ippin : flesh yellow, rather firm, crisp: juicy, rich flavor : best. Dec, to Fel.

Stark. Fruit large; skin greenish yellow, shaded, splashed and striped with light and dark red. Joderately juicy, mild sub-acicl. January to May.

$\checkmark$ Talman's Sweeting. Medium; light yellow, with a pale blush: rich and excellent, very productive. December to $A$ pril.

Twenty Ounce. Fruit large and slowy: greenish yellow, boldly splashed and marblert with stripes of red: good to very good. October to January.

Wagener. Merlium, dark red; mild, tender sub-acid; excellent variety, abmulant be ner. December to Marcli.

Walbridge. Frnit nedium size: pale whitish yellow when fnlly mature; flesh white, fine, crisp. tender and juicy. January to IIay.

Wealthy. Medium size: whitish yellow, shaded with deep rich crimson fiesh white, tine wrained, tender, juicy, lively sub-acid; hardy and productive. Iecember to February.

Winesap. Medium, dark red: yellow flesh, firm, crisp, high flavored ; fruit hangs late on the tree; excellent for cider, very good bearer, and excellent keeper. December to May.

Winter Sweet Paradise. Pennsylvania apple, hardy and productive: green when picked, with brown fhush, beconing paler at maturity: ffesh white, fine grainet. juicy and very gool. November to March. 
Wolf River. Very hardy ; fruit very large, whitish color, mostly covered with red and numerous brown specks. Flesh firm, sub-acid. Regular and enormoús bearer. March.

York Imperial. A very fine Pennsylvania apple of medium size, oblate, white, shaded with crimson; flesh firm, crisp, juicy sub-acid. November to February.

\section{CRAB APPLES.}

Red Siberian. Small; bright red, covered with a light transparent bloom; excelleut for preserving. Early September.

Yellow Siberian. Small; pale yellow, also very valuable for preserving. September.

Gen. Grant. Fruit round, of large size for a crab; skin cream yellow ground, broken stripes, becoming red on sun exposed side. Very mild sub-acid. October.

Hyslop. Large; dark red, with a blue bloom; good for cider.

Marengo. Large; bright red on yellow ground : flesh white, crisp, juicy ; when fully ripe, mild, pleasant sub-acid. Early Winter to late Spring.

Quaker Beauty. Tree strong grower, spreading habit, bearing large crops alternate years; fruit large, conical, with beautiful red cheek on a groundwork of white; quality best. December to May.

Transcendant. Large, yellow; mostly covered with red; productive and desirable. Best early Fall variety.

Van Wyck Sweet. A valuable variety. Fruit large; skin yellowish white, colored red and covered with bloom; flesh sweet and tender; core small. September.

Whitney's No. 20. A seedling of the Siberian crab. Said to be large, striped, almost red : flesh yellowish white, very juicy, sub-acid. Good for canning and making into cider. August.

\section{PEARS}

Dwarf Pears. For small gardens and for cultivation by amateurs, or persons likely to devote the necessary attention to them, Dwarf Pears will certainly prove remunerative in a suitable soll, and with proper selection of varieties. On very light sandy soil, or gravelly soils, Dwarf Pears will not prove so well as-

Standard Pears. These are generally preferred for orchard culture. They will not bear fruit at so early an age as Dwarf Pears, but they will flourish on a greater variety of soils, and will bear neglect better : without proper cultivation, however, they will, like most trees, fail to give satisfaction.

Gathering Pears. Pears, as a general rule, should never be allowed to ripen on the tree. Summer and Fall varieties should be gathered at least ten days before maturity: Winter Pears about the time frosty weather sets in.

The varieties marked with a star $\left.{ }^{*}\right)$ succeed well as Dwarfs. The following list includes the most valuable varieties:

\section{SUMMER VARIETIES.}

Bartlett. Large; clear yellow skin ; buttery, very juicy and high flavored , early and great bearer. September.

*Clapp's Favorite. Large, resembling Bartlett; ripens a few days earlier; prodnctive. August and September.

Doyenne d'Ete. (Summer Doyenne.) Small; yellow, with red cheek; rich, sugary, melting; very early and fine. Last of July. 
Le Conte. Fruit large: skin smooth, pale yellow; good quality. 'Tree very vigorous, said to be free from blight. Very prolific. October.

* Osband's Summer. Medium size, rich yellow color : excellent quality mild and pleasant flavor. Itugust,

Tyson. Medium : yellow, reddish cheek; very melting and juicy, sweet, excellent flavor; very productive. September.

\section{FALL VARIETIES.}

*Beurre d'Anjou. Iarge; yellowish, somewhat russeted, red clieek ; fine grained, buttery, melting and excellent. October to December.

* Bufrum. Above medium; obloug, leep yellow, with reddish cheek, somewhat russeterl; buttery, sweet and good flavor; a great bearer. september to October.

*Duchesse d'Angouleme. T'ery large, dull yellow; buttery, rich, juicy, and excellent; flocs best as a dwarf. October to November.

Flemish Beauty. Large: greenish yellow, russeted; sweet and rich, excellent flavor; productive, September and October.

* Howell. A fine large pear, sweet and melting; pale yellow, with a red cheek ank patches of russet $t$. September and october.

* Louise Bonne de Jersey. lurge, beautiful, first-rate pear; pale green with a dark blush : buttery, juicy auch rich. September and October.

Kieffer's Hybrid. Isarge and sllowy; supposed to be a seedling of a Sand Pear accidentally crosserl with some cultivated kind grown near it. Skin is a rich yellow color, tinged with reel. Wicellent for cannigg purposes. Very productive. () ctoluer.

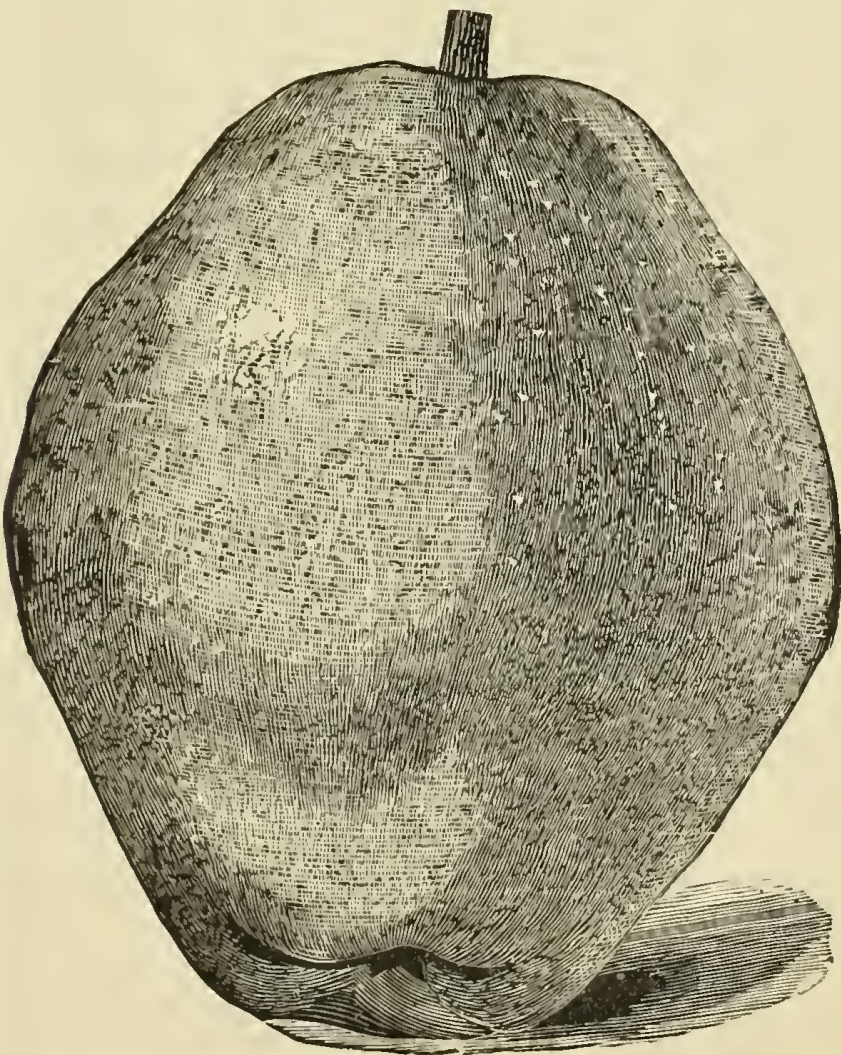

KIEEFER PEAR. 
Seckel. Small; dull yellow, with russet and colored cheek; very juicy, buttery and rich : very high flavored and productive; a slow grower. September and October.

Sheldon. Above medium; dark yellow or russet; rich, melting and high flavored; first rate quality. October and November.

\section{WINTER VARIETIES.}

Duchesse de Bordeaux. A new, large, French variety ; good quality and very prolific. February to April.

Lawrence. Medium; light yellow, mostly sprinkled with dots; buttery, rich and aromatic; very reliable and productive. December.

* Vicar of Wakefield. Large, long, yellow, often a red cheek; juicy and very pleasant; very productive. November to January.

\section{CHE RIES.}

The cherry will prove successful on light, well drained soil. Any tree that is attacked by the "black knot," can be saved by cutting off all indication of the disease as it appears. The following list embraces the really desirable kinds.

\section{CLASS I-HEART.}

Black Eagle. A fine, large, black cherry, of first rate quality and productive; very sweet and rich; one of the best. First of July.

Black Tartarian. Very large, black, half tender ; sweet, rather rich, fine flavor; deserves general cultivation; tree a strong, upright, beautiful grower and good bearer. Last of June.

Coe's Transparent. Medium size, amber color, red cheek; very tender and sweet; very desirable. June.

$\checkmark$ Downer's Late Red. Above medium; light red mottled with amber; melting and delicious, excellent, very productive; not subject to rot by rainy weather. July.

Early Purple Cuigne. Medium, dark purple; juicy, tender and sweet. Early in June.

Elton. Large, pale yellow, streaked and mottled with red; half tender, juicy, rich and delicious. June and July.

Governor Wood. (Dr. Kirtland's.) Large; light yellow, shaded with red; tender, rich and delicious; one of the best. I Last of June.

Ohio Beauty. (Dr. Kirtund's.) Large; dark and pale red marbled; tender, juicy, high flavored. Towards end of June.

Ox-Heart. Large; red skin, red and half tender flesh, pleasant juice, of second quality in point of flavor. Iast of June.

\section{CLASS II-BIGARREAU.}

Napoleon. Very large; pale yellow, spotted with deep red; very firm and juicy ; ver's productive, and a constant bearer. First of July.

Rockport Bigarreau. Large, light red; firm and juicy, very fine flavor; productive. First of June.

Schmidt's Bigarreau. Largest black cherry; flesh dark, tender, juicy, with a fine rich flavor.

Yellow Spanish. Large; light yellow, witl led cheek, having a waxen appearance; firm, juicy and sweet; one of the best, very productive. Last of June.

Windsor. Originated in Canada. Fruit large, liver-colored, resembling Elkhory or Tradescant's Black Heart; firm and of fine quality. Tree hardy and very prolific. A valuable late variety. New.

\section{CLASS III-DUKE AND MORELLO.}

Belle de Choisy. Medium, amber, mottled with red; tender, juicy, sweet and rich. Last of June.

English Morello. Medium to large, blackish red; rich acid, juicy and 
good ; very productive and reliable. Is not the old "Common Morello." Very pardy. August.

Early Richmond. (Kentish.) Medium size, dark red; melting, juicy, sprightly, rich acid flavor: very productive, reliable and hardy; valuable. Jume

$\checkmark$ Late Duke. Large, light led: late and fine. Last of July.

May Duke. Larwe, dark red; juicy and rich; an old, excellent variety, vigorous and productive. Midclle of June.

Montmorency. (Ordiurlire) large and hardy, said to be seven to ten days later than the Richmond. Very productive and valuable.

Olivet. A new, remarkably early cherry: productive, fine quality and the largest of its class. ('olor, shining deep red; flivor sub-acid ; ripens early in Jume aud continues till July.

Reine Hortense. Very fine, large, bright red; juicy and delicions, vigorous and productive. Ripening from the first to the middle of July.

\section{PLUMS.}

A heary soil, with a considerable mixture of clayey loam, is most suitable for the Plum. It should be planted where the hogs and poultry have free access, as the latter destroy many injurious insects, and the former, in rubbing against the tree, jar it and eat the fallen fruit. Where no hogs are kept, the trees should he jarred once a day, and all fallen fruit at once gathered and destroyed. Mr. Bateham, of Ohio, writes the Conntry Gontlemon that by applying sulphur over the trees, in putting it in a bag to a long pole and shaking it over the trees, spleudid crops have been realized.

Coe's Colden Drop. Very large: oval, pale yellow; flesh firm, adheres to the stone; very valuable. Last of Feptember.

Ceneral Hand. Very large, yellow; flesh juicy and pleasant. September.

Cerman Prune. I arge, oblong, purple; juicy and riclı; tree very productive: untsually free from the Curculio and from knots. September.

Huling's Superb. Very large and handsome, yellowish green: adheres to the stone. Middle of August.

Imperial Gage. large, oval: greenish yellow, covered with bloom, very juicy and sweet: one of the most valuable varieties. Middle of August.

Kelsey's Japan. Large, heart shaped, rich yellow, nearly overspread with bright red, with a lovely bloom; flesh rich, juicy and firm with small pit. Not hardy nortl of New York city.

Magnum Bonum. Yellow, one of our largest plums; egg-shaped, very productive : excellent for cooking. Last of August.

Mariana. Seedling of Wild Goose: very landsome and good, exceedingly prolitic: an earty bearer and free from the ravages of the curculio; deep cardiual red, when ripe; thick skin, fine quality.

Peach. Very large, nesrly round, dull red: rather coarse grained, but juicy and good Hawored; much valued for its size aud b.auty; tree a good bearer and grower. Eud of Angust.

Prince Englebert. liark blue, of good quality; tree a great bearer and a strong grower; i valuable market fruit. Last of August.

Prunus Simoni. (A pricot $I$ Plum.) From the Orient, and therefore not hardy enough to be profitable hele. Ripens in July, is brick red with yellow flesh of an odd flavor. An acquisition further south.

Reine Claude de Bavay. Large, roundish; greenish yellow, juicy, melting and excellent; tree a good growel aud bearer. Last of september.

Richland. Small, purplish green: sweet and agreeable; excellent for cooking purposes, aud said to withstand the attacks of the curculio better than mgst varieties; evidently a seedling of the Blue Dauson. First of September.

Shipper's Pride. Said to be an unfailing cropper and a good shipper. Large, ronnd purple plim of excellent quality.

Shropshire Damson. An English variety, fruit suluall, rather obovate; skin purple, covered with tbick, blue bloom; flesh melting and juicy, rather tart; separates partially from the stone. Thousands of bushels are annually sold in the market for preserves. With good cultivation it is enoruously productive. September. 
Union Purple. Large; purple covered with thin bloom; flesh greenish, sweet and good; tree a strong grower. September.

Wild Coose. An improved variety of the Chickasaw, of strong growth and comparatively free from injuries of the Curculio: large, bright red, with a gray bloom; juicy, sweet and good; very productive and profitable. Last of July.

\section{PEACHES.}

The peach will succeed best on light. gravelly soil; with proper cultivation, on almost any soil. Trees one year old from the bud are best suited for planting. The orchard should be kept cultivated, and the trees carefully examined every Spring to extract the borers. A shovel full of lime applied at the base of each tree will of ten be a preventive as well as a fertilizer. The disease called the "Yellows" is incurable; therefore if it shows itself on one or two trees, these must be cut down at once and burnt, which will save the whole orchard. This disease has never shown itself in the nurseries; my trees have always been healthy and given entire satisfaction.

My stock of peach trees is quite extensive: they can be supplied in almost any quantities and on liberal terms.

The following varieties are described in the order of ripening :

\section{FIRST RIPENING.}

Amsden's June. Fruit good size, delicious flavor; finely colored red, free stone and very firm, White flesh, excellent quality. First part of July.

Alexander. Very large and highly colored; handsome, rich and good flavor: flesh thick and firm; will carry well long distances. Freestone. First part of July.

Waterloo. Medium size; excellent quality, flesh white, skin greenish white, purplish red on side exposed to the sun.

\section{SECOND RIPENING.}

Early Beatrice. Medium size, marbled red cheek; flesh melting and very juicy. Grood shipping peach; great bearer. Freestone. Middle of July.

Early Rivers. Large, pale yellow with pink cheek; flesh melting, very rich. Freestone. Last of July.

\section{THIRD RIPENING.}

Barnard's Early. A large yellow peach of good quality. Very popular in the Western States.

Hale's Early. Beantiful peach; white flesh, of excellent quality when well ripened. Rots in some localities. Freestone. Last of July.

Troth's Early Red. Medium size, skin ed; flesh yellowish white, juicy, sweet and excellent; good market peach. Frestone. First of August.

Mountain Rose. Large, red skin, white flesh ; excellent quality. Free stone. First of August.

George the Fourth. Large, pale yellowish white with red cheek; flesh pale, yellowish white, very juicy and rich; moderate bearer, of best quality. Freestone. August.

Large Early York. (Honest John.) Lar se, white skin and nearly white flesh; tender and juicy; very pruductive. Freestone. August.

Foster. Tery large and handsome; very similar to Crawford's Early, but ripens a few days earlier; yellow flesh. Freestone.

Crawford's Early Melacoton. Very large, yellow with led cheek; yellow flesh, red at the stonf; very juicy and excellent; one of the test. Freestone. Middle of August.

\section{FOURTH RIPENING.}

Yellow Rareripe. Large, deep yellow, lotted with, red; flesh yellow, red at the stone, melting, juicy, rich; excellent vinuus fiavor. Freestone. Latter part of August. 
Wager. Very large, yellow: bears uniform and large crops: juicy and fine tavor. I,ast of Aligist.

Richmond. Medinm to large, yellow mottled with red, flesh yellow, meltins juicy, rich. Freestone. First of Feptember.

Old Mixon Free. Isarge, vellowisl white with a dark rerl cheek: white, teuder fleslı: excellent viriety for narket. Frestone. First part of September.

Old Mixon Cling. Resembles in quality the Old Mixon Free. It is an excellent cliuะstone peach: white flesh. September.

Reeves' Favorite. large, romdish; yellow flesh, red at the stone; excellent guality, hardy variety. Freestone. September.

Morris WhIte. An old well known variety. Rather large, whiti a skin: white flesh to the stone, a little firm, meltins, juicy. sweet and rich. In sone sections tender and variable in quality. Freestone. Midd e of September.

Red Cheek Melacoton. Very large; skin yellow, deep red cheek ; flesh yellow, juicy and vinous; very productive; a favorite market fruit. Freestone. September.

Wheatland. Large to very large; quality best: deep golden yellow; great benler, excellent shipper. Freestone. Ripens between Crawfords Farly and late.

\section{FIFTH RIPENING.}

Susquehanna. Very large and handsome; rich yellow with a beantiful rerl cheek: yellow fiesh, melting, rich and fine. Moderate bearer. Freestone. September.

Stump the World. Very large, creany white with red cheek; white flesll, rich and high flavor; very productive, valuable for marketing. Freestone. Sejtember.

alobe. Very large, golden yellow; very fine flavor, ripening during the latter half of september.

$\checkmark$ Hill's Chili. large, skin woolly, dull yellow: flesh yellow, very rich and sweet. Iroductive and hardy. Freestone. Last of September.

Crawford's Late Melacoton. Very large; yellow with a deep red cheek: rellow flesh, red at the stone: a very excellent variety. Freestone. Septeruther

Fox's Seedling. Large, beautiful rad cheek; white flesh, fine quality; good shipper.

Ward's Late Free. Rather large, white with crimson cheek; flesh white, juicy and rich; a popular and good market variety. Latter part of September.

\section{SIXTH RIPENING.}

Clarissa. A new and rery large peach; yellow, fine flavor and appearance. Very valuable on acconnt of its late ripening.

Chair's Choice. Fine yellow freestone; rich in color, splendid flavor, excollent for cimning. lipening with Snock.

Sener. Large, yellow: with deep red cheek; yellow flesh, deep piuk around the stome. Freestone, sweet, rach and very juicy. Ripens about October lu. Highly recommended at the Centennial Exhibition.

Smock. large, oval; deep vellow with red cheek; flesh yellow, red at the stone. juicy and rich. Freestone. Last of September and early October.

Stephen's Rareripe. Large, resembles Old Vixon's Free, but more lirghly colored. Very prolitable.

\section{SEVENTH RIPENINC.}

Bilyeu's Late October. A large white flesh, freestone with a beantiful blush cheek: flesh rich, juicy and firm. A good shipper. Ripens two weeks later than Snlock. Best late peach yet introduced.

Heath Cling. Very large, white, tinged next to the sun. quite downy : flesh white, very juicy, sweet, of it ligh, rich, excellest flavor. Clingstone. October.

Lord Palmerston. A beautiful, large and very late peach. Fruit of a pale color, having a little red on the sunny side: flesh firm and richly flavored.

Salway. large, yellow, mottled with a red clieek; yellow flesh, very productive: valuable for its late ripening. Freestone. Uctober.

Steadley. A late freestone: ripening ten days after Ifeath Cling: also said to be laruer, and of very fille flavor 


\section{DWARF PEACHES.}

Italian Dwarf. A very interesting little tree; it bears soon, sometimes when only two years old: the fruit is of good quality, small size; the tree does not grow higher than about 2 to 3 feet, therefore well suited for pot culture.

Colden Dwarf. (T'an Buren's.) Medium; skin yellow with a mottled, red cheek: juicy, rich and luscious : bears good crops; grows about 4 feet high ; clingstone. September and October. hardy.

Downing's Everbearing. Large, black; sweet and excellent. Not very

New American. Tree a fine grower; productive and hardy. Excellent. Fruit blackish.

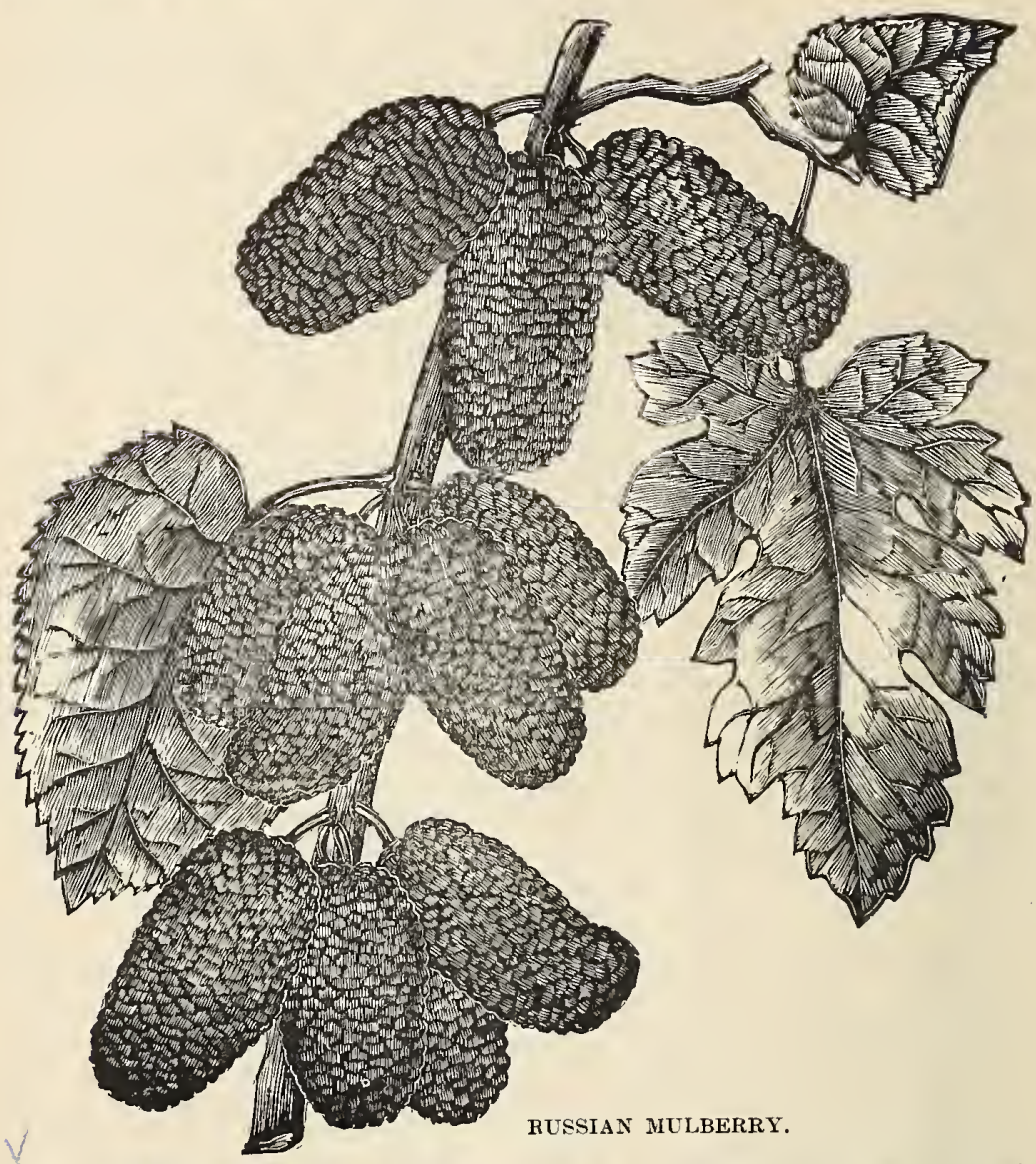

Russian. Fruit large, about the size of Kittatinny Blackberries, mostly black; sub-acid to sweet; very productive; perfectly hardy. The original trees were imported from western Russia.

White. Is the common variety; white fruit. 


\section{QUINCES.}

Apple, or Orange Quince. Fruit large, bright golden yellow; excellent for preserves; very productive.

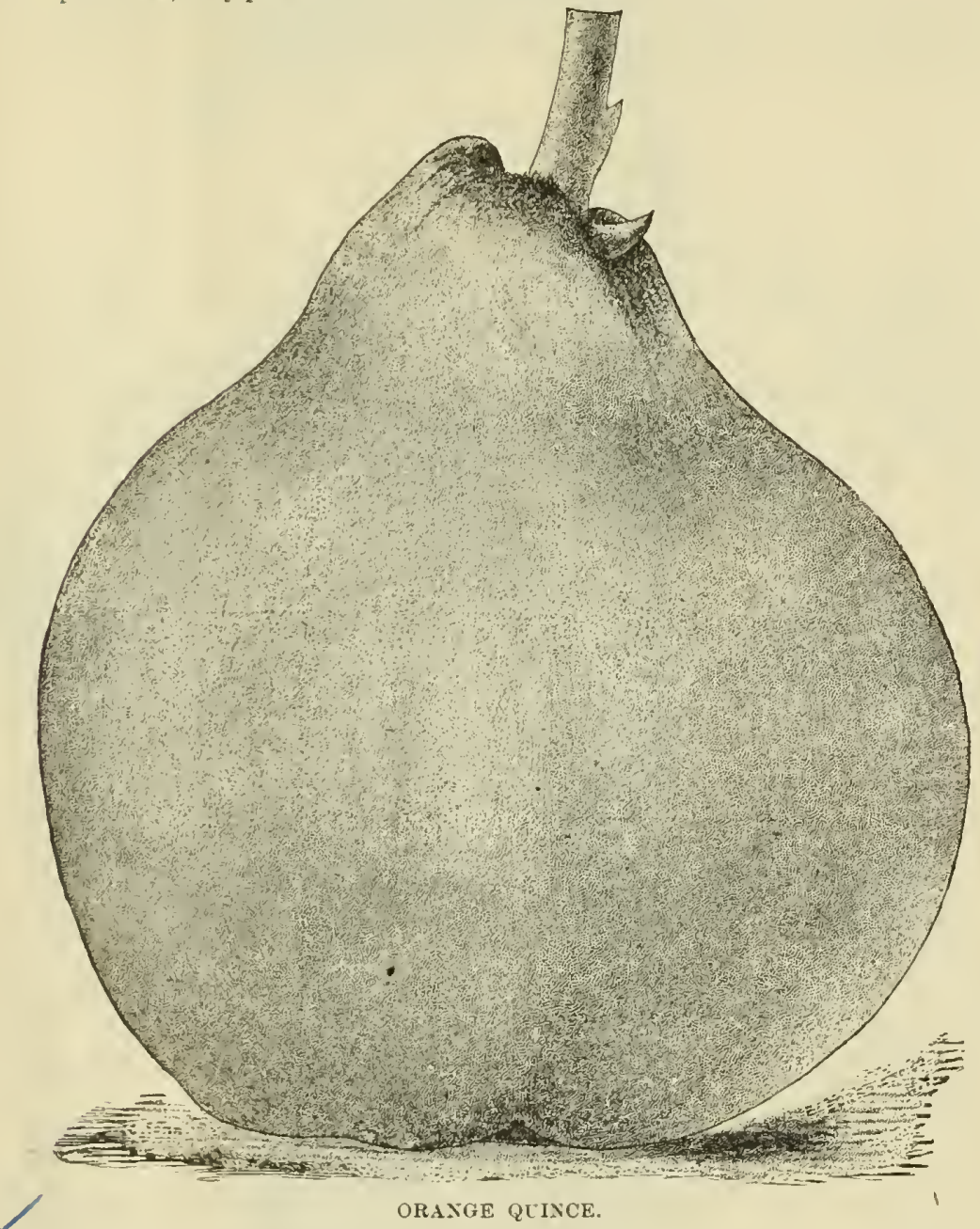

Champion. A new variety, originating in Connecticut. Tree a prolific and constant bearer. Fruit larger than the Orange, equally as fine, and a longer keeper.

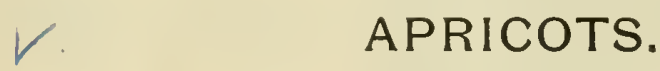

Breda. Small, round, orange; flesh juicy, rich and vinous; hardy and a good bearer. July to A ugust.

Early Golden. Small, roundish, pale orange; flesh yellow, juicy, sweet. and good; vigorous grower and productive. July. 
Large Early. Large, oblong; orange, with a red cheek; juicy, rich sweet, fine flavored. July.

Moorpark. T'ery large; orange, with a reddish cheek; flesh orange, sweet, juicy, with a fine flavor; a very valuable variety. Beginning of August.

Peach. Tery large, yellow; flesh rich, juicy and high flavored; one of the best, if not the best. Beginning of August.

Russian. From Russia, and claimed to be very hardy; fruit medium size and best quality. Last of August.

\title{
NECTARINES,
}

\author{
(A Tariety of the Peach, with a smooth skin.)
}

Boston. Large: light yellow, with a red cheek; flesh yellow, sweet and pleasant. First of September.

Downton. Large, pale green, with a red cheek; melting, rich, excellent. Last of August.

Early Newington. Large; pale green, nearly covered with blotches of red; juicy, rich and sweet: probably the best clingstone nectarine.

Elruge. Medium size; pale green, covered with purplish red, juicy and very rich. August to September.

\section{NUTS.}

Of these I mention Hard and Soft-shell Almonds, Spanish Chestn ut and English Walnut, (the last two are rather tender when young:) Black Walnut and Shell-bark (Curya albr.)

\section{GRAPES.}

Agawam. (Rogers' No. 15.) Bunch and berry large round and dark red. flesh juicy, rather tender, aromatic; ripens soon after Concord.

Brighton. A cross of Concord and Diana Hamburg: hardy; berries resemble the Catawba: ripens same time as Hartford Prolific. Tery productive where it does well.

Catawba. An old, well-known kind; berries of rather large size, deep red, covered with lilac bloom. On account of mildewing very badly, it proves worthless in many localities; where it does well it is excellent.

Champion. Bunch and berry medium, black: with handsome bloom, oval shaped, thin skinned; soft pulp; sweet taste; ripen $10 \mathrm{or} 15$ days earlier than Hartford Prolific, and shows good shipping qualities.

Christine or Telegraph. Bunch above medium, very compact; berry large, round, black: flesh juicy, sweet and good: hardy and strong grower: earlier than Hartford Prolific; it does not mildew, therefore reliable.

Clinton. Bunch large; berry small, black, covered with a blue bloom; juicy, sweet and excellent; very productive and reliable; does not mildew; makes excellent wine.

Concord. A well-known standard variety; bunch and berry large, black, covered with a blue bloom; juicy, street and excellent; very reliable, does not millew; quite early; good for the table and making wine.

Delaware. Bunch small to medium, compact; berries below medium, of beautiful red or purplish maroon color, covered with a thin whitish bloom; thin skin, pulp sweet and tender, very juicy: quality best for table and for wine. Hardy; mildews in some localities, often produced by overbearing. A very poorgrower.

Eaton. New; berries very large; black, covered with thick bloom; bunch large and compact; thick skin; very juicy. Highly commended.

Elvira. Bunch medium, very compact; berry medium, round, pale green with white bloom, sometimes tinged with red streaks when fully ripe; rery thin 


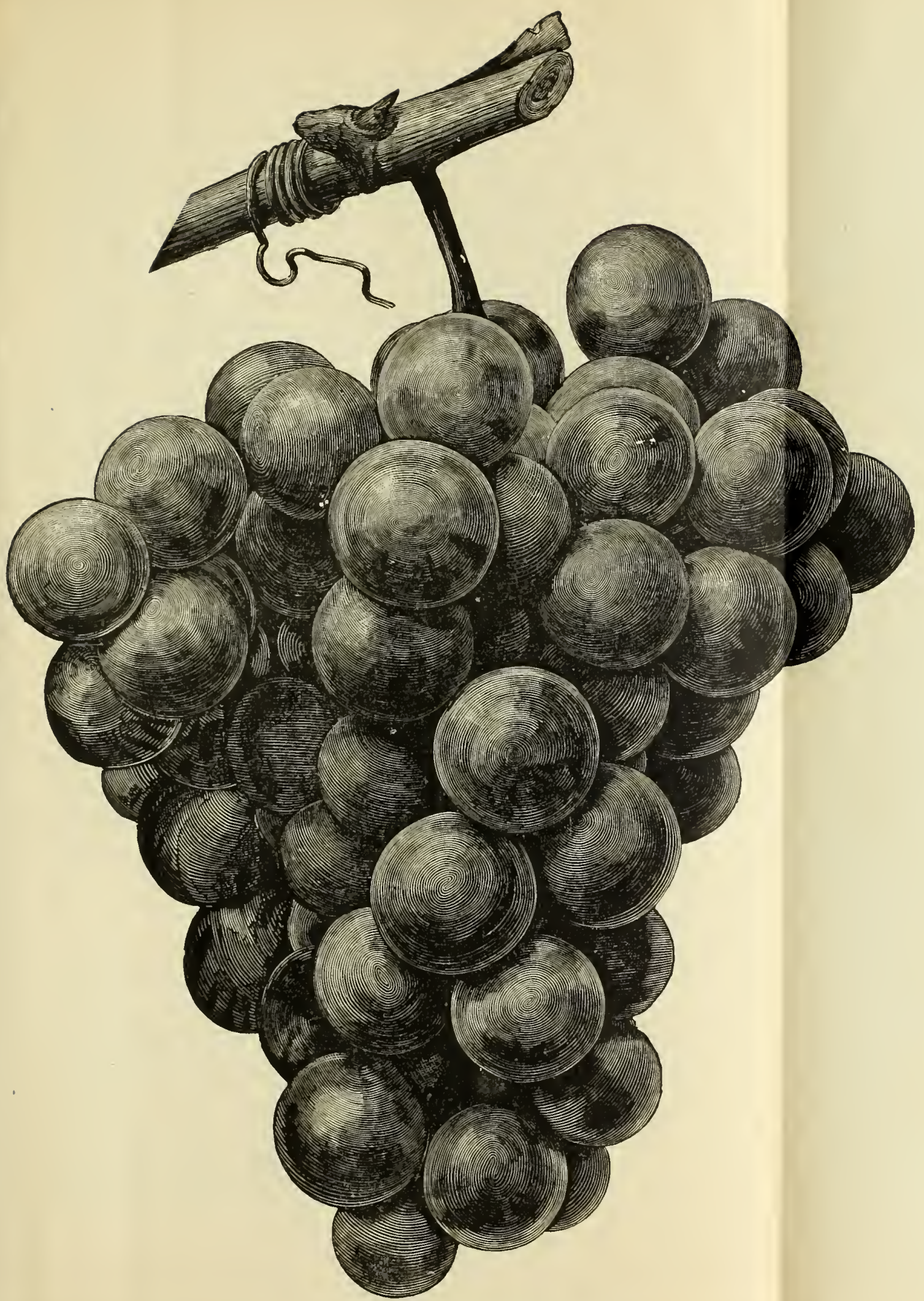

EATON GRAPE. 

skin: ripens ten days later than the Concord; very productive; vigorous grower, exceedingly healthy and hardy; excellent for white wine. New variety, but very promising.

Empire State. A seedling of Hartford Prolific and Clinton, therefore purely native. Berry medium to large, white with a slight tinge of yellow, covered with bloom: tender, juicy, sweet Ripens with Hartford.

Hartford Prolific. Bunch large, rather compact; berries round, full, medium, black: flesh juicy. Hardy and healthy, very productive and reliable. Does not mildew:

Jefferson. Berry light led; tender, juicy and sweet. Bunch large and compact; ripens a little after Concol'l.

Lady. Seedling from the concord; bunch and berry large, light greenish yellow with white bloom; early, acd said to be hardy, healthy, productive and reliable; very sinilar to Martha.

Lady Washington. Bunch and berry large, showy and beautiful: skin pale yellow: tender, juicy and sweet flesh, of good quality. Ripens with Concord and keeps a long time in bearing.

$\checkmark$ Lutie. Originated in Tennessee. Belry red, good size, but not first-class quality: rather foxy. Yine is a very strong grower, and has healthy foliage. Not so liable to mildew as the finer sorts.

Martha. Most popular among the old white varieties; bunch and berry medium: thin skin, greenish white, sometimes with an anber tinge; very healthy, hardy and productive; ripens a few days earlier than the Concord. Does not mildew.

Moore's Early. Bunch and berry large, round; very hardy and entirely exempt from mildew; early: very desirable. Resembles Concord in its excellent qualities, but ripens before Hartford Prolific.

Niagara. Berry greenish white, large, skin thin but does not crack, good quality and productive. Hardy. Bunch conyact.

Pocklington. A seedling of the Concord, raised by Mr. John Pocklington of Sand Hill, $\mathbf{N}$. $Y$. The vine is a strong grower and harly, identical with the Concord, having large, thick foliage, and like that variety never mildews. Fruit. large, light golden yellow color: bunches very large, often shouldered: berries round and thickly set on the bunch. Ripens with Concord.

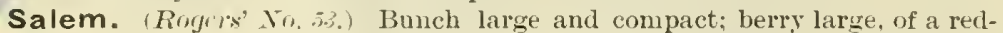
dish color: Hesh tolerably tender, sweet, with a rich aromatic flavor. Does better in the western than in the eastern part of Penusylyania.

Telegraph. See Christine.

Woodruff Red. A seedling of Concord. Large red berry of indifferent quality. Good grower, healtly foliage. May do well in localities where finer grapes mildew.

Worden's Seedling. A liandsome, large black grape. It is larger, of a better quality, and earlier than the Concord.

Vergennes. A hardy, productive grape, ripening with Hartford Prolific, and is a cood shipper. Bunch and berry large, with a delicious flavor. In color it is a shade lighter than the Catawba.

\section{BLACKBERRIES.}

Plant in rows six feet apart, four feet apart in the rows. An annual dressiug of manure will prove very profitable.

Erie. Tery large, hardy, very early and very productive. Of excellent qual. ity, handsome and firm.

Kittatinny. Tery large, slightly conical. The berries are flrm, of sweet, excellent flavor, and are perfectly ripe as soon as they turn black. It is a vigorous grower, hardy and very productive: continues four or five weeks bearing. The best blackberry for general cultivation. diums.

Taylor. Hardy and productive. Berries large and fine flavor. Season me-

Wilson's Early. Large, oval, pointed: flavor rich and good: ripens very early, and matures the whole crop in two weeks.

Wachusett Thornless. Medium size, sweet and good. A zood keeper rendering it a valuable market variety: succeeds on both light and heavy soils. A hardy variety, almost free from thorns. 


\section{RASPBERRIES.}

Plant in rows five or six feet apart, four feet apart in the rows. Remove all the old canes as soon as the fruit is gone, and do not allow more than three or four new ones to each hill.

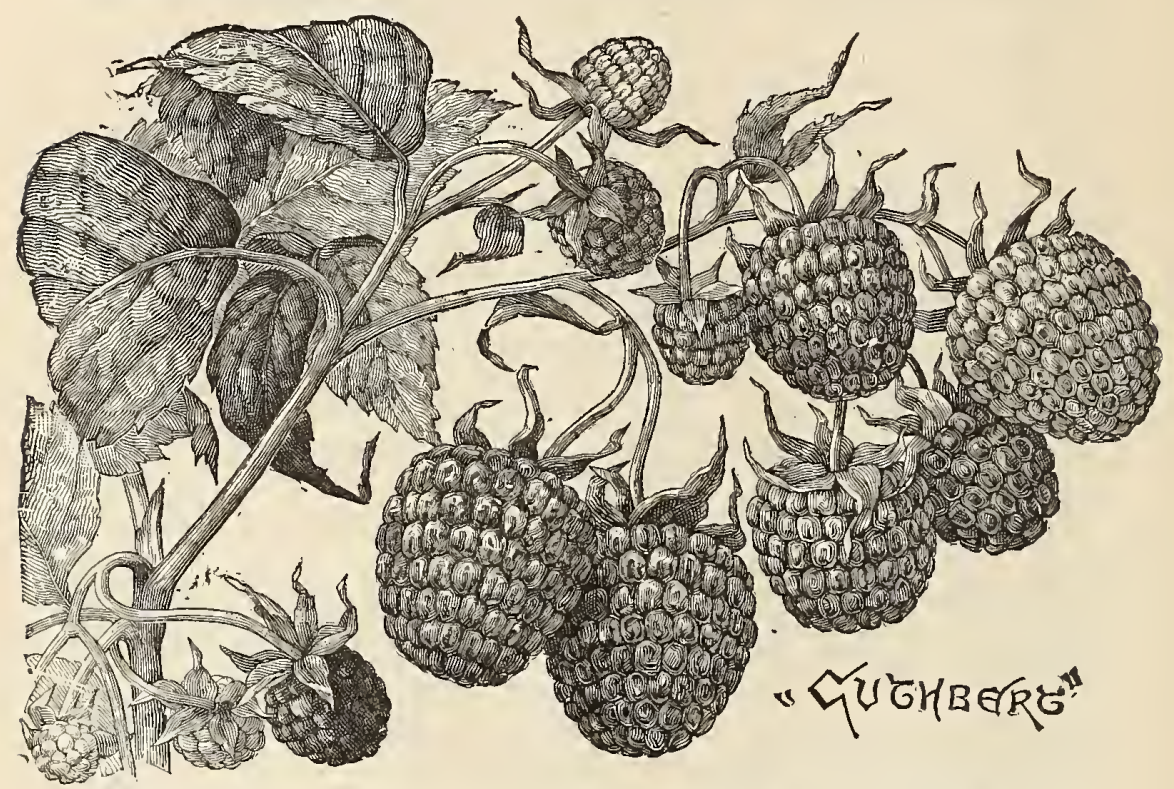

Cuthbert. A strong, hardy variety; berries large, rich crimson and of a good flavor; flesh is so firm that it can be shipped hundreds of miles safely.

$\checkmark$ Doolittle Black Cap. Large, black; sweet, early, productive and hardy; a profitable market berry.

Gregg. Recently introduced from Ohio; ripens with Mammoth Cluster, but larger, more productive and of finer quality. The best.

Hansell's Eearly. Medium to large; color of the brightest crimson; good quality; canes vigorous and hardy. Said to be the earliest of all raspberries.

Mammoth Cluster. Large, black, juicy; late and very productive.

\section{STRAWBERRIES.}

To cultivate the Strawberry for family use, we recommend planting in stools two or three feet apart, and to keep all the runners off. By this treatment the fruit will be superior in size, as well as in flavor.

Strawberry plants generally do better planted in the Spring, at any time before they are in blossom. If planted early in the Fall, the plants generally suffer from want of rain; and if planted late in the Fall, the plants will not become sufficiently established to withstand the Winter.

Of the long list of varieties now introduced, the following have proven to be the most valuable for general cultivation.

Crescent Seedling. Very productive; good quality, fair size, good color and solid flesh.

Manchester. A large, firm berry of excellent quality, brilliant scarlet in color. It continues in fruit for a long season and is wonderfully prolific. 
Monarch of the West. Very large; bright color; firm, with a superior flavor; a fine grower and very prolific.

Sharpless. V'ery large : excellent quality, great productiveness, firmness of fruit and vigor of plant all mombined.

\section{GOOSEBERRIES.}

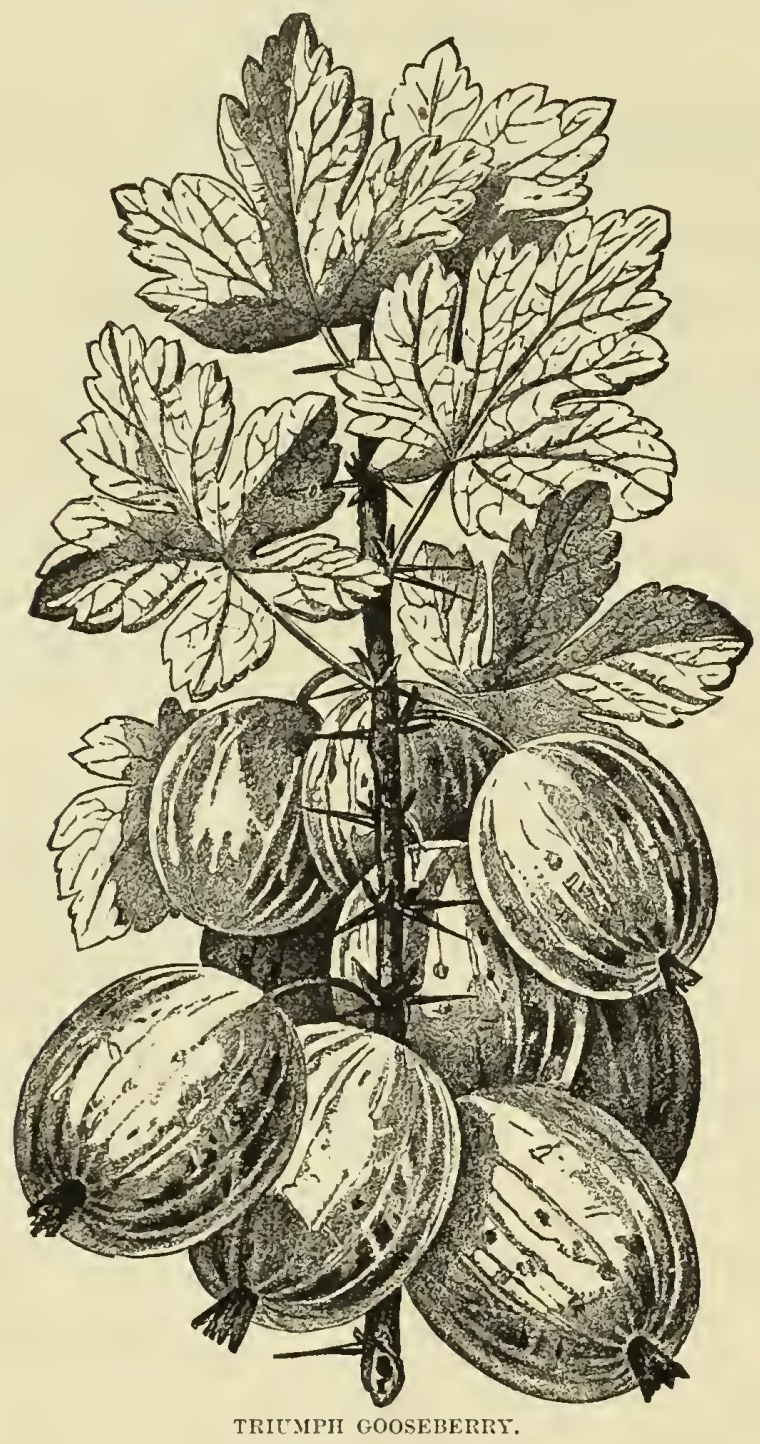

Triumph. A nci American seedling, which is being introduced now. The fruit is very large, of yellowish green color. The original plants, which have fruited for more than ten jears, have never mildewed, and proved exceedingly productive. 
Downing. Upright, vigorous growing plant; very productive ; fruit somewhat larger than Houghton, oval; whitish green, skin smooth; flesh soft and juicy, very good; excellent for family use.

Houghton's Seedling. A hardy American variety of great excellence; free from mildew and enormously productive.

Industry. An English variety; fine, large red berries. Will mildew in some. localities.

\section{CURRANTS.}

These can be profitably grown, planted between fruit trees, when the latter are so young as not to shade the ground too much.

Black Naples. A large, productive, black currant.

Cherry. The largest of all currants; bunch short, berries very large; deep red, acid.

Fay's Prolific. Red; very productive and from its peculiar stem ine $\mathrm{x}$ e sive to pick.

La Versaillaise. A French variety; bunches and berries very large, very productive; one of the most desirable varieties.

Red Dutch. An old and very popular variety; dark red, very productive, and the best paying variety for the market.

White Crape. Bunch and berry very large; whitish yellow, transparent; a spreading, irregular grower; the best white Currant in cultivation; very productive.

\section{ASPARAGUS AND RHUBARB}

The best kinds can be furnished at these Nurseries. 


\section{ORNAMENTAL DEPARTMENT.}

\section{DECIDUOUS TREES.}

Of the following Ornamental Trees I can furnish medium size and extra size trees at proportionate prices:

APPLE. (Pyrus.)

Double Flowering. (P. Spcetabilis.) Also called the Chinese Crap Apple. A native of China; grows 20 to 30 feet high ; of different flowering varieties,

\section{ASH. (Fruxinus.)}

American White. (F. Americtur.) A native tree of large size, rapid growth and easy cultivation; leaves pinnate, pale green and handsome.

All the Ash varieties must be carefully examined armually at the base of the tree, to kill the borer, which often attacks it in A pril or May.

\section{BEЕСН. (Fugus.)}

American. (F. fermulncr.) A large native tree, with smooth bark, horizontal, spreading branches and coarsely toothed foliage.

Cut-Leaved. (F. luciniutr.) of medium growth, cone shaped and compact; presents a peculiar, airy outline from its small, cut-leaved foliage. Very choice.

European. (F. sulvaticn.) A native of Europe; foliage larger and more compact than the preceding; grows very large.

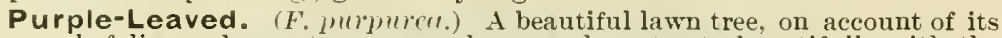
rich purple foliage: does not grow very large, and contrasts beautifully with the green foliage of other trees.

Weeping. (F.s. pcurlulu.) The finest large tree of drooping habit. Onght to be more extensively introduced.

\section{BIRCH. (Bctulu.)}

Weeping. (B. allm.) A rery ornamental tree, with silvery white bark and fine foliage: its branches droop.

Purple-Leaved. New; very striking and attractive, an elegant lawn tree ; leaves very dark glossy purple.

Weeping Cut-Leaved. (B. urticafolin.) The habit is very much of the former: the toliage presents a finer appearance, being more deeply cut and fernlike. It does better in the Northern States.

Young's Weeping. (B. allor pentulu Youngii.) Droops to the ground in fine thread-like shoots; beautiful. The best of the weeping birches.

\section{CATALPA, or INDIAN BEAN. (Citalpa.)}

Hardy. (C. specinst.) An npright, rapid grower, trees being straight and tall. Having stood the severe winters of the Northern States there can be no doubt as to its hardiness.

\section{CHESTNUT. (Custrencre)}

American Sweet. (C. vescle Amcricrma.) A native tree, well known. Its nuts are smaller but much sweeter and better flavored than the European species.

Spanish Chestnut. (Crstriner icser.) The nuts are larger than the American but not as sweet.

CHERRY. (Cerusus.)

Bird Cherry. (C. murtus.) Tree of small size, but of unexceptional shape, bearing a profusion of fragrant, white flowers in long racemes.

Double Flowering. Pretty double white flowers. 


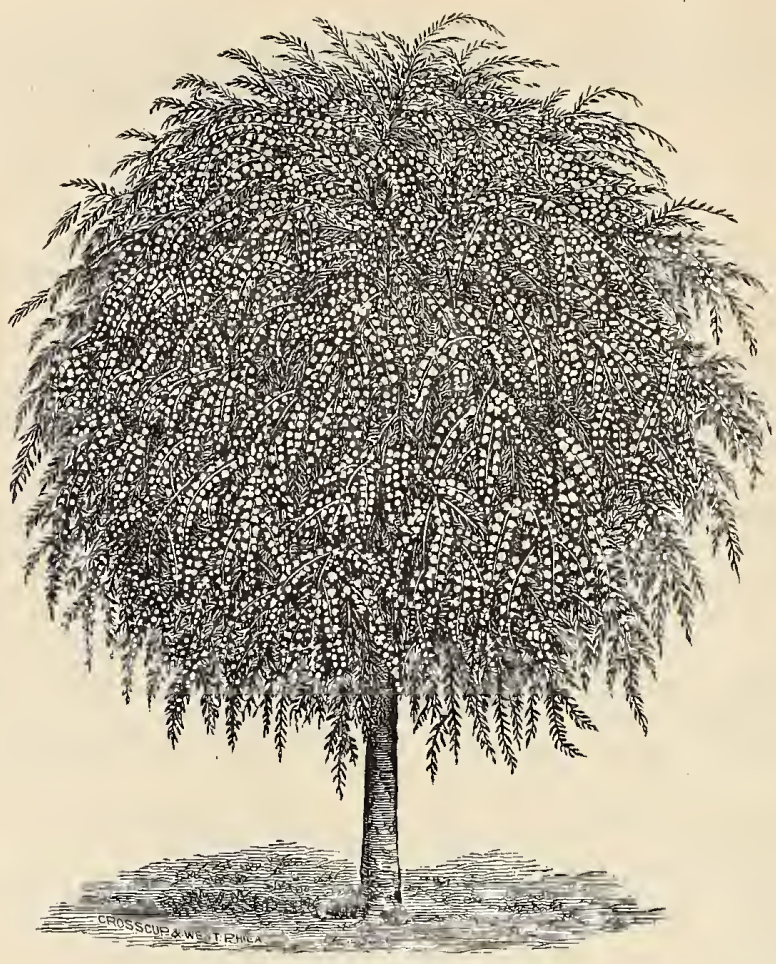

DWARF WEEPING CHERRY, IN BLOOM.

Dwarf Weeping. (C. pendula.) The finest of all small weeping trees, it makes a dense round head, has beautiful, glossy, small leaves ; bears white flowers profusely, and also a few dark red, sour cherries.

\section{CYPRESS. (Taxodium.)}

Deciduous. ( $T$. distichum.) A most beautiful small growing tree, with delicate pale green, fine foliage, similar to an evergreen; handsome in groups or planted singly.

Weeping Deciduous. ( $T$. pendulus.) From China and Japan; a small tree of an upright conical shape, with the young branchlets all drooping. The foliage is exceedingly graceful and delicate.

DOGWOOD. (Cornus.)

White Flowering. (C. Florida.) Very ornamental: ought to be more appreciated; of fine form and beautiful foliage; produces white flowers early in the Spring.

Red. With blood red bark; very conspicuous in Winter.

Weeping Dogwood. A variety of C. Florida with branches drooping decidedly. Very ornamental.

ELM. (UTmus.)

Are not recommendable for Pennsylvania, the leaves becoming skeletonized by insects during the summer. They thrive well in Northern States.

American White or Weeping. (U. Americana "alba.) The noble, graceful and drooping tree of our own forest. growth.

English. ( $U$. Campestris.) A stately tree, pyramidal in its habit and

GINKO TREE. See Maiden Hair Tree. 
HAWTHORN. (Cratcous.)

Double Flowering Hawthorn-Red. A beautiful little shrub-like tree, with very double red or deep crinson blossoms. white.

Double Flowering Hawthorn-White. Like the above, but flowers

\section{HAZELNUT, or FILBERT. (Corylus.)}

Common. (C. (evelluna.)

\section{HORSE-CHESTNUT. (Fsculus.)}

English. (E. himporastumum.) A hardy, healthy tree, free from diseases; bears white flowers, spotted with purple and yellow; makes a very dense shade; grows slow.

Dwarf. (.E. purviflort.) From our Southern States, but hardy here. A large shrub, with numerous panicles of pure white flowers, blooming in May.

\section{HICKORY. (Carya.)}

Shellbark. (C. $a l h a$.$) This splendid forest tree is too well known to need$ description. The great difficulty of transplanting is the cause of it not being more common in nurseries.

JU DAS TREE. (Cercis.)

American. (C. Canudensis.) A small growing tree; covered with delicate pink flowers before the leaves appear.

English. (C. siliquastrum, Very much like the American.

\section{LABURN UM. (Cytisus.)}

Golden Chain. Bears long pendant racemes of yellow flowers in June; showy and beautiful; an elegant tree.

\section{LARCH. (Larix.)}

European. (L. Europer.) An elegant, rapid growing, pyramidal tree, also valuable for timber; small branches, drooping.

\section{LINDEN. (Tilia.)}

European. ( $T$. Europert.) A very fine pyramidal tree, with large leaves and fragrant flowers; desirable on large grounds.

American, or Basswood. ( $T$. Americunu.) A rapid growing, beautiful native tree, with very large leaves and fragrant flowers.

Weeping. ( $T$. allor pendulu.) A charming lawn tree, with rery graceful drooping branches and downy white leaves. It is rapid in growth, entirely hardy, and very conspicuous in a collection.

\section{MAIDEN HAIR TREE. (Salisburia.)}

Ginko-tree. (S. adiantifolin.) A rare and beautiful tree, with remarkable fan-like foliage. A native of Japan; it thrives well here.

\section{MAGNOLIA.}

Sweet Bay, or Swamp Magnolia. (M. glalucr.) A small growing tree: flowers deliciously fragrant, cup shaped, and pure white. An American variety.

Large-Leaved. (M. mucrophyllu.) A medium sized tree, with very large leaves, 1 to 2 feet long ; flowers very large, pure white and fragrant. A rare Anierican variety.

Umbrella. ( $\boldsymbol{M}$. tripctclu.) A medium sized tree of rapid growth; large leaves and large, cream white flowers. An American variety.

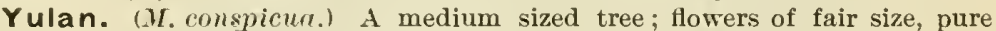
white, fragrant, and opening before the leaves appear. An Asiatic variety.

Slender Crowing. ( $H$. gracilis.) A small tree, or rather a large shrub; flowers cup shaped, dark purple without and white within.

Purple Flowering. (H. purpurea.) Darker and shorter leaves than the preceding; flowers are outside dark purple, shaded to white at the apex, and inside white. 


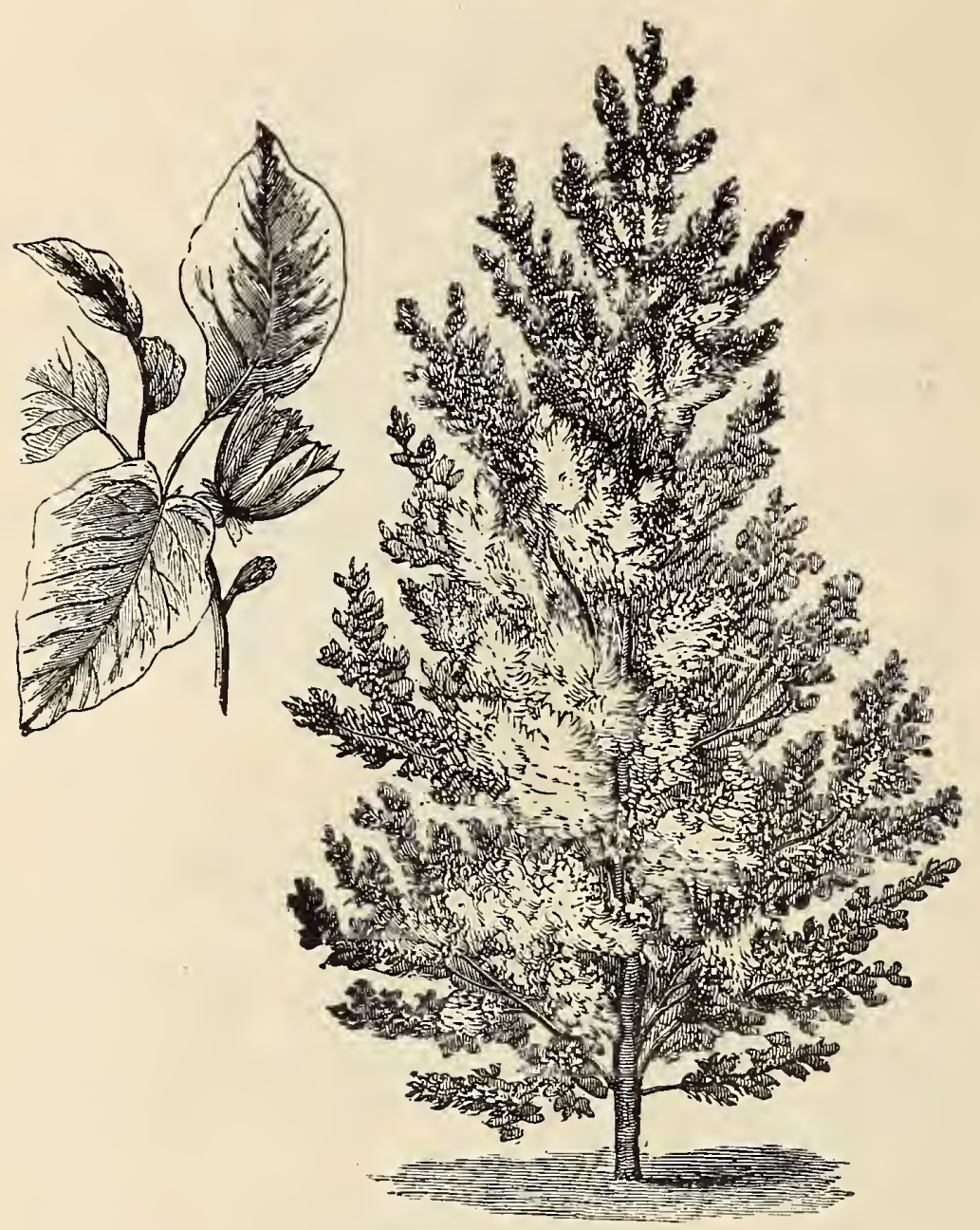

MAGNOLIA ACUMINATA.

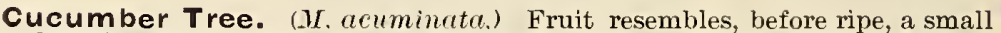
cucumber; beautiful, regular conical shape; glossy leaves; flowers medium size, greenish yellow, bell shaped. An American variety, of rapid growth, reaching the height of 60 or 70 feet.

Soulange's. ( $M$. Soulangeana.) A hybrid between $M$. purpurea and $M$. acuminate; flowers purple and white; very handsome.

MAPLE, (Acer.)

Norway. (A. platrnoidcs.) One of the most valuable ornamental trees for the street and lawn; rich, dark green foliage, compact growth, free from insects and diseases: a splendid shade tree.

Red or Swamp. (A, rubrum.) A native tree, medium size; the foliage turning in the fall to various tints of yellow and red. A good street tree.

Silver-Leaved. (A. dasycarpum.) Of exceedingly rapid growth, and desirable for immediate effect.

Sugar, or Rock. (A. succharinum) A very popular American tree : and for its stately form and fine foliage, justly ranked among the very best, both for the lawn or avenue. Leaves turn golden yellow in the fall. 
sycamore. (A. pseurlo platınus.) A handsome, rapid growing tree; rich, dark foliage.

Weir's Cut-Leaved Silver. (A. (l. Hririiluciniutum.) A weeping graceful silver maple, with leaves deeply cut. One of the best.

\section{MOUNTAIN ASH. (Sorbus.)}

European. (N. (Iurupmin.) A fine bardy tree: head dense and regular covered from July till winter with large clusters of bright scarlet berries.

Oak-Leaved. (S. Incupuriu quercifoliu.) The leaves are of a downy white color underneath, and deeply toothed on the margins: harly and fine.

Weeping. (S. rucuprrir monlulu.) A beautiful tree with straggling, weeping branches; makes a fine tree for the lawn; suitable for covering arbors.

All varieties of the Mountain Ash are liable to be attacked by the borer; an annual examination at the base of the trunk of the tree is advisable.

PEACH. (Persiru.)

Blood-Leaved. Has dark purple leaves, and bears fruit.

Double-Flowering. White; very ornamental.

Double-Flowering. Pink.

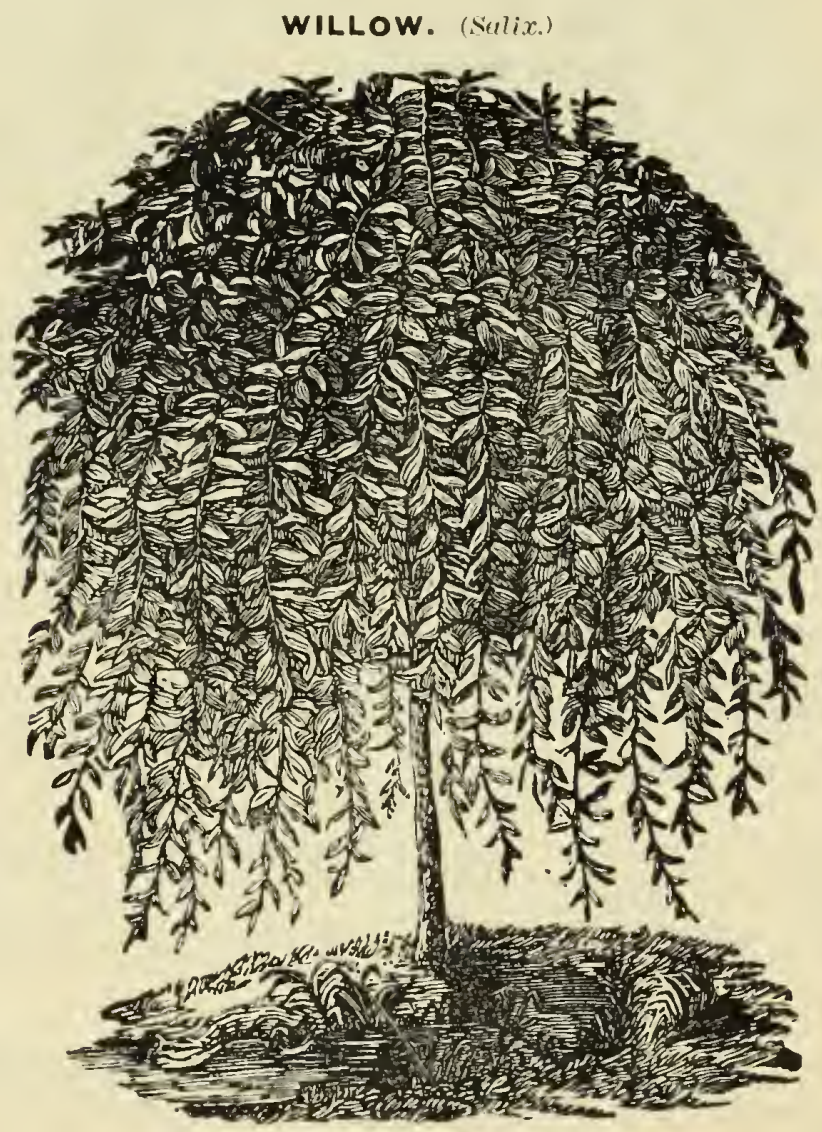

KILHARNOCK WILLOW.

Kilmarnock Weeping. (S. criprer molulu) i variety of the Goat Willow; an exceedingly graceful little tree; very harly. 
Common Weeping. (S.Babylonica.) The well known Weeping Willow beautiful, and invaluable for watery scenery and low grounds.

American Weeping. (S. Americana pendula.) An American, small, slender branched tree; very ornamental.

Rosemary-Leaved. (S. rosmarinifolia.) A shrub; native of this country, with lanceolate, silky leaves. Grown also as a tree by grafting.

POPLAR.. (Populus.)

Cottonwood, or Carolina. ( $P$. angulata.) Branches acutely angular or winged; leaves very large, heart shaped, shining; grows rapidly.

Lombardy. ( $P$. dilatata.) A very fast and high growing, pyramidal shaped tree; creates marked effect in large groups.

SWEET GUM. (Liquid amber styraciflua.)

A beautifnI street tree, with large, glossy leaves, resembling the Maples, tur $\mathrm{n}$ ing deep crimson in the fall.

TULIP TREE. (Liriodendron.)

White Wood, erroneously Yellow Poplar. (L. tulipifera.) One of our most beautiful native trees, of tall, stately growth, with large, smooth, shining leaves; greenish yellow flowers, tulip shaped.

YELLOW WOOD. (Virgilia lutea.)

A middle sized, round headed tree, which, when in bloom bears flowers, hanging in clusters of whitish yellow color; is particularly ornamental.

\section{EVERGREEN TREES.}

\section{ARBOR VITÆE. (Thuya.)}

American. ( $T$. occidcntalis.) Excellent for screens and bedges.

Globe. (T. Globosa.) A favorite dwarf; globular dense bush; makes fine low hedges

Golden. (T. aurea.) A splendid variety of a yellowish tint.

Parson's Dwarf. (T. compacta.) Remarkable for its compact growth ; dwarf, with bright green foliage; one of the very best dwarf Arbor Vitæs. Very suitable for hedges around cemetery lots.

Pyramidal. (T. pyramidalis.) Is remarkably erect; dark green, compact and very desirable.

Rollinson's Colden. (T. clegantissima.) An upright grower, having a rich golden hue; very conspicuous.

Siberian. ( $T$. Sibcrica.) Maintains its dark green color in winter ; is very hardy; compact and pyramidal in growth.

FIR. (Picea.)

Balsam. (P. balsamca.) A well known American evergreen, pyramidal in form, with deep green foliage; an erect, rapid grower. Beautiful; makes a fine Christmas tree.

European Silver. (P. pectinata.) A fine tree resembles the Balsam Fir, but has more horizontal branches and more silvery foliage. It is superior to the Balsam Fir.

JUNIPER. (Juniperus.)

Irish. (J.hibernica.) Very erect and tapering in its growth, forming a column of deep green foliage; a pretty and distinct evergreen, which for its beauty and hardihood is a general favorite. Very suitable for small yards and cemetery lots.

Swedish. (J. suecica.) Similar to the Irish, though not so erect; has blueish green foliage, and forms a handsome pyramidal small tree.

Trailing. [J. Squamata. $]$ A beautiful trailing plant. 


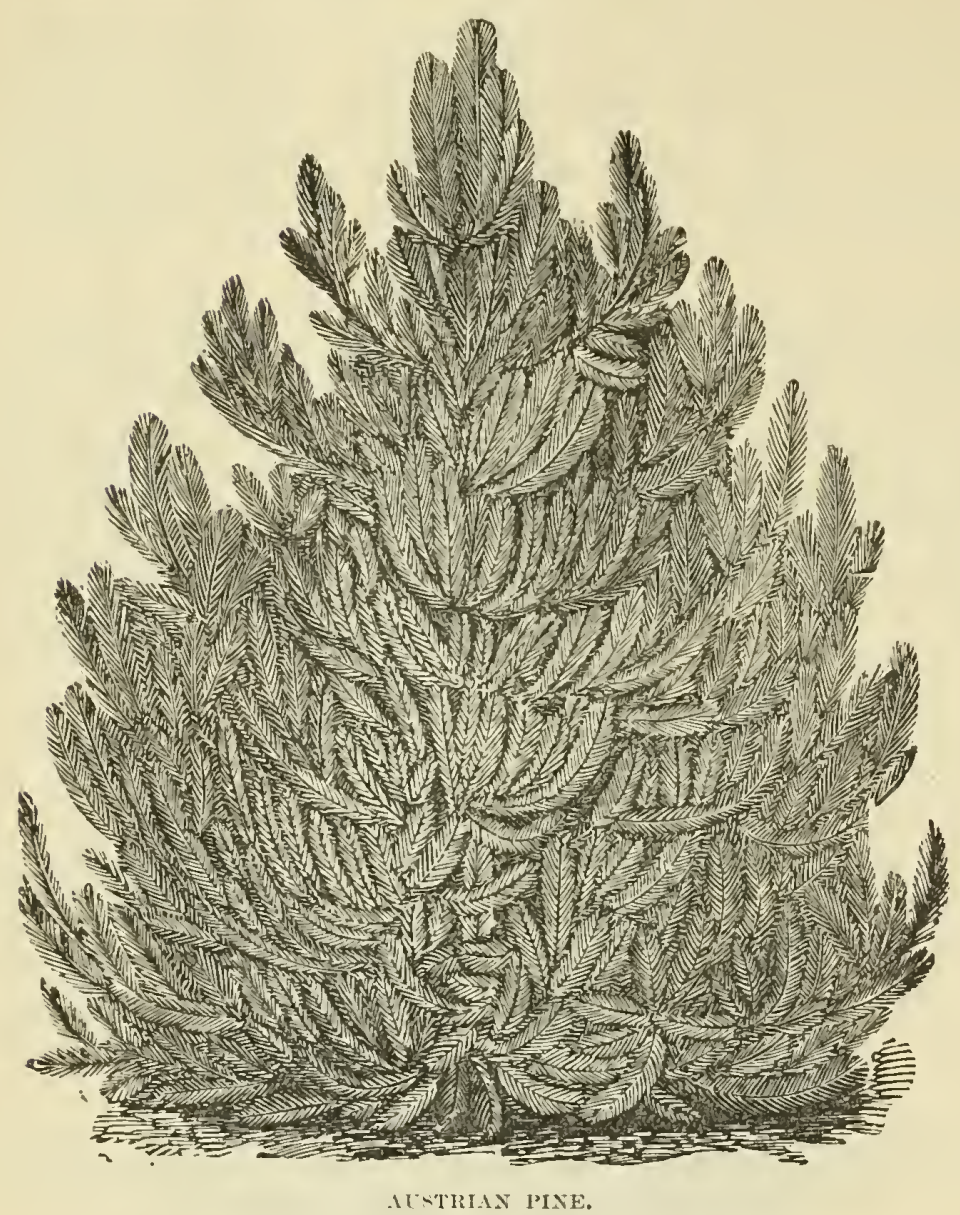

PINE.S. (Pinus.)

Austrian or Black. ( $P$. mustrinrm.) A very remarkably robust, hardy, spreading tree; leaves long, stiff, and dark green; yrowth rapid; valuable for this country.

Dwarf or Mountain. (P. mmilı.) A low, spreading, curious species, attaining only the size of a bush. Foliage similar to that of the scotch.

Scotch. (P.Sylvestris.) A fine, robust, rapid growing tree, with stout, erect shoots, and silvery green foliage.

White. ( $I$, strolnus.) The most ornamental of all our native Pines. Foliage light, delicate and silvery green. Flourishes in the poorest soils.

Stone. (P. rembra.) A handsome tree, of compact, conical form, and low glowth while young.

RETINOSPORA. (Japrin Cyprus.)

Compacta. New, beautiful green during the whole year; branches;erect and grows compact.

Obtusa. A beautiful, harly variety; grows from 60 to 80 feet high, with graceful, drooping branches. Leaves glossy green above, silvery white bands beneath.

Fernlike. (Filiferu.) Delicate, slender branches. Very striking and graceful. Perfectly hardy. 


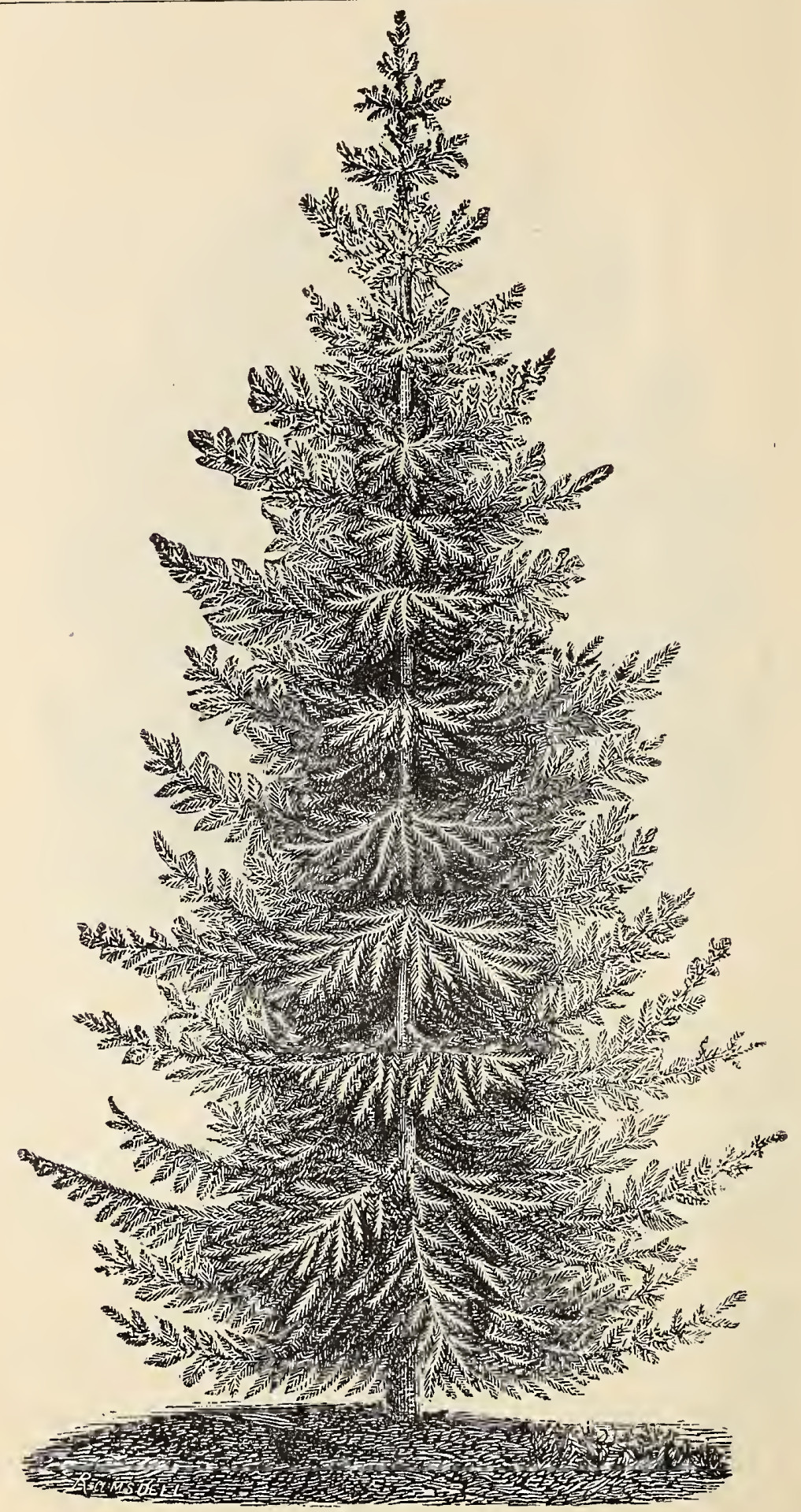

NORWAT SPRUCE. 
Gracilis. Dwarfish, fan-like branchlets at the end of branches. Very picturesque in its growtl.

Golden. (R. Mlumasu aurea.) One of the most striking and desirable little plants for this climate; tips of branches of a bright golden hue; it is entirely hardy and preserves its color well. Beantiful.

Plumosa. Compact, bright green, entirely hardy. Tery pretty.

Squarrosa Sieboldti. A heath-leaved form of this class. Resembles the Thuy Ericoides, but is hardier than the latter. Foliage light bluish green. Hardy and handsone.

\section{SPRUCE. (Alies.)}

Hemlock, or Weeping. (A. crumlensis.) Au elegant pyramidal tree with drooping branches and delicate, dark foliage, like that of the Yew. Distinct from all other trees. It is a beautiful lawn tree, and makes a highly ornamental hedge.

Norway. (A. exrelsa.) A lofty, elegant tree of perfect pyramidal habit ; remarkably elegant and rich, and, when old, has fine, pendulous branches. It $\mathrm{i}_{\mathrm{S}}$ exceedingly picturesque and beautifnl. Thousands are sold for Christmas trees.

Oriental Spruce. From the shores of the Black sea. A beautiful tree, compact and slender foliage.

White American. (A, albr.) A medium sized, native tree of comprot growth, regnlar conical shape, light green color' entirely liardy and succeeds in most situations. A beautifnl tree.

\section{DECIDUOUS SHRUBS.}

\section{ALTHEA. (Hit)isculs.}

Rose of Sharon. (H. Nyriurus.) A handsome, strong-growing shrub. valued on account of its late blooming-in August and September: niakes an ormamental hedge.

Of these are grown Double White, Double Red, Double Purple and Bicolor, which is pink and white.

Variegated Leaved Althea. The foliage is finely marked with light yellow. Produces purple flowers. One of the finest rariegated slurubs.

ALMOND. (Amiy!grtulus.)

Dwarf Double Flowering. (.1. mmilu, $t ., l$.) Blooms in May veryprofusely, the whole bush being literally covered with flowers. There ire double pink and white varieties, both exceedingly beatiful.

BER BERRY. (Berluris.)

Purple. (B. vulg. murpurru.) An upright, thorny shrub having dark purple leaves. Planterl anong other shrubbery it is in striking and beautiful contrast. Flowers in Mar or Jnne.

CURRANT. (Rilles:

Yellow Flowering. (R. rurcum.) A native shrub with yellow flowers: also called the "Missouri Cnrrant." Flowers in May.

\section{DEUTZIA. (Dintzin.)}

Double Flowering, Pure White. (D. rrenutacandidissima.) Like D. Crenata, but pure white.

Pride of Rochester. Tery much like the Double-flowering Crenata. The flowers are a little larger and it blooms profusely.

Double Flowering. ( $I$. crenutr $H . \mu l$.) Very much like the preceding, only its flowers are double and delicately margined with pink, which makes it more rlesirable. Very nice for bouquets. Tune.

Rough-Leaved. (D. scrima.) A leautiful slirub with profuse, white drooping tlowers. Flowers in Jnne.

Slender-Branched. (I). gracilis.) A charming species, introduced from 
Japan, and entirely hardy; flowers pure white, graceful and delicate. As the flowers are much used for bouquets, it is often grown in pots in the greenhouse, where it will flower at a low temperature in winter. June.

Scalloped-Leaved. (D. crenata.) A!so from Japan; thrives well here, and has myriads of drooping white bells. Flowers in June.

\section{DOGWOOD. (Cornus.)}

Red-Branched. (C. Sanguinea.) Has blood-red bark; very conspicuous in winter. Blooms in May.

White. C. florida.) See Deciduous Trees.

Variegated-Leaved. Leaves beautifully variegated with white, making it a very attractive and desirable variety.

\section{GOLDEN BELL. (Forsythia.)}

Very Green. ( $F$. viridissima.) The most common, and the best kind of this class. Bright yellow flowers; one of the first to bloom in Spring. Blooms before the leaves appear. April or May.

\section{ELDER. (Sambucus.)}

Golden-Leaved. ( S. aurea.) Has very bright, golden-yellow leaves. A valuable plant for enlivening shrubberies.

\section{HONEYSUCKLE, Upright. (Loniccra.)}

White. (L. Tartarica albiflora.) Nearly pure white flowers. May.

Yellow, or Fly Honeysuckle. (L. Xylosteum.) Small, cream-colored flowers. May.

Large-Flowering. (L. grandiflora.) Flowers very numerous, of deep red coior. May.

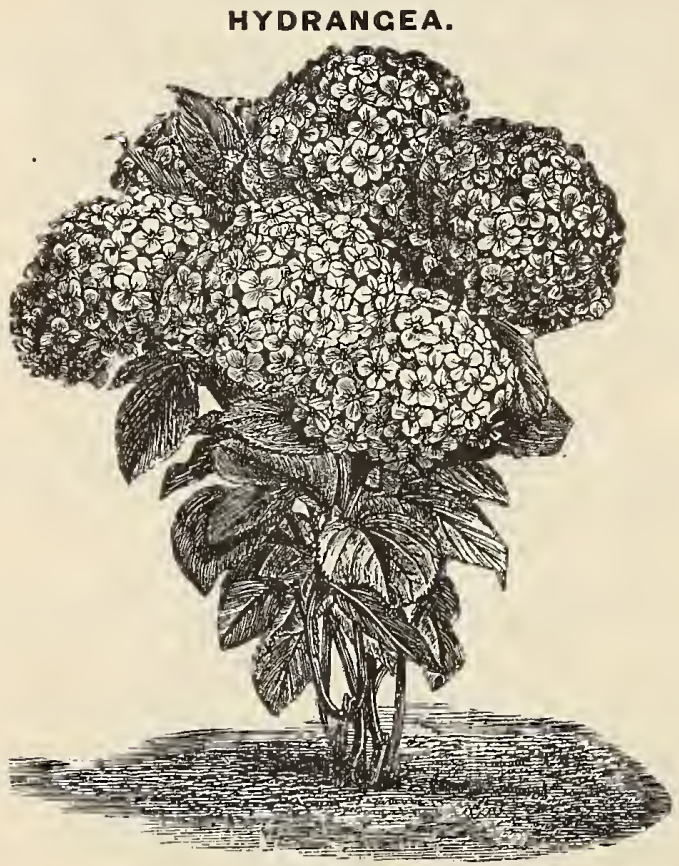

HYDRAXYGEA.

Paniculata. (H. Paniculata grandiflora.) Flowers in large panicles, pure white; the plant is entirely hardy. Blooms from early August till frost. 
LILAC. (Syringre.)

Common Purple. (\$. vulgucis.) Well known shmub; purple, fragrant flowels. Flowers in llay.

White. (s. rllm.) like the preceding, except the flowers, which are nearly white. Hlooms in May.

Persian Purple. (র゙. I'crsicu.) Beautiful; one of the best. May.

Persian White. (S. P'rsica riba). Blusll white. May.

MIST-TREE. (Rhus cotiuus.)

This trec is kuown under various nannes, as Purple Fringe-tree, Smoke-tree, Purple Mist, etc. It is a very beautiful, (listinct, large shrub, rather than tree; very much admired for its long, feathery fruit stalks, which give the tree the appearance of being covered with a cloud of smoke. It makes a striking olject upon the liwn. Jume and July.

\section{MOCK ORANGE OR SYRINGA. (Philudelphus)} flowers.

Double Flowering. A variety with partially double, very fragrant

Colden-Leaved. A very pretty plant of medium size, with golden-yellow foliage. Keeps its color the entire season.

Large Flowering. ( $P^{\prime}$. gromdillorus.) A large shrub, covered with a profusion of white, showy Hower's in June.

Sweet Scented. (I'. coronurius.) Flowers not so large as the preceding, but very fragrant. Flowers in Jume.

PLUM. (Prunus.)

Double Flowering. ( $P$. trilolur.) of recent introdnction from China; has pretty, semi-double, pink flowers, elosely set along the branches, forming com: pact spikes. l3looms in May.

Purple-Leaved. (P.I'issurrli.) Pmple leaves, retaining its color all season ; very protty. Hlowers small, white, single.

\section{PRIVET. (Ligustrum.)}

California. (L. omulifoliuu.) Nearly evelorem, strong growing shrub with hright green, meflimm-simed leaves; white flowers in Jume. Very oruamental. 'The hest of all the l'rivets.

\section{QUINCE, JAPAN. (Cyrlomir.)}

Red Flowering. (1:.Jripulert.) An old and esteemed varicty, having a profusion of bright, scarlet flowers in early spring; one of the best hardy shrubs we have. Makes a beautiful and nseful heige. May.

\section{SNOWBALL. (Viburnum.)}

Opulus. A well known favorite shmb of large size, with globular clusters of white fluwers, blooming early in June.

JAPAN. ( $\boldsymbol{I}^{\top}$. plicuturu.) A rare and exceedingly beautiful species; flowers pure white, in very large globular heads.

\section{SPIREA or MEADOW SWEET. (spirca.)}

Billard's. (S. Billurdi.) Rose-colored; blooms nearly all summer.

Bumalda. Similar to the Callosa alba in habit and growth, but flowers are pink. June.

Crispifolia. From Japan. Very dwarf, pink flowers. Blooms nearly all suniner.

Fortune's Dwarf White. (S. callose altra.) A small form of the following, with pure white flowers. Very listinct. June and July.

Fortune's (s. rallosa, or Foctulii.) A fine variety with large panicles of (leep rosy blossoms, which continue neally all summer.

Colden-Leaved. (s. opulifolia (unrea.) Very conspicuons from the golden sellow hne of its foliage. Jume. 
Plum-Leaved. (S. prunifolia.) Small, glossy leaves, very distinct; has numerous small, double white flowers; blooms in May.

Reeves'. (s. Recevesii.) Long, narrow leaves, and large corymbs of white flowers that cover nearly the whole plant. May.

Reeves' Double Flowering. (S. Recvesii $/ l . p l$. ) A double variety of the preceding; very fine. May.

Thunberg's. (\$. Thmmhroii.) A Japanese species of small size, with narrow linear leaves and small white flowers; unsurpasserl for forcing in pots. Flowers in May.

\section{SWEET-SCENTED SHRUB, or ATREPIER. (Calycanthus floridus.)}

A favorite shrub, with fragrant wood and flowers of a rich, chocolate color, rich foliage; blussoming in June, and at intervals throughont the season.

\section{SNOWBERRY. (Symphoricarpus.)}

Red Fruited, or Indian Currant. (S. mulgaris.) Has red berries that stay on all winter; quite showy. June.

Snowberry. (S. raccmosus.) A well known shrub, with small pink flowers and large white berries, that remain on the plant through part of the winter. June.

\section{STRAWBERRY TREE. (Euomymus.)}

American Burning Bush. (E. atropurpurcus.) A native shrub, 3 or 4 feet high, with bright green ovate leaves and greenish purple flowers; crimson pods. June.

European Burning Bush. (E. Emropens.) A native, very ornamental shrub of Europe; has brilliant, rose-colored herries, which hang in clusters from the branches until midwinter; planted with evergreens the contrast is very fine. June.;

\section{TAMARIX.}

African. ( $T$. Africana.) This is a very beautiful shrnb, with small leaves somewhat like the Juniper, and delicate small flowers in spikes. June.

\section{WEIGELA. (Dicrvilla.)}

Rose Colored. (D. rose $a$.) An elesant shrub, with profuse, fine, rosecolored flowers; introduced from China by Mr. Fortune and considered one of the finest plants he has discovered. Quite hardy, blooms in May and June.

Amabilis, or Splendens. Of much more robust habit, larger foliage and flowers, and blooms freely in the Fall.

Profuse Flowering. (b. multiflora floribunda.) Small deep crimson flowers throughout the season.

Variegated-Leaved. (D. foliis variegata.) A new variety; leaves very ornamental, distinctly marked with yellowish white and green; hardy. Flowers in June.

Candida. Bears white flowers; blooms profusely. It is the most desirable of the white kinds. June.

\section{WHITE FRINGE. (Chionanthus.)}

Virginia. (C. Virginica.) One of the best large shrubs or small trees; has superb foliage and delicate fringe-like, greenish white flowers. June.

\section{EVERGREEN SHRUBS.}

ADAM'S NEEDLE. (Tucca.)

Thready. (I. filumentosu.) Stout, lance shaped foliage; the flower stalk rises from the centre, bearing numerous creamy white, bell-shaped flowers. Quite a tropical looking plant. 


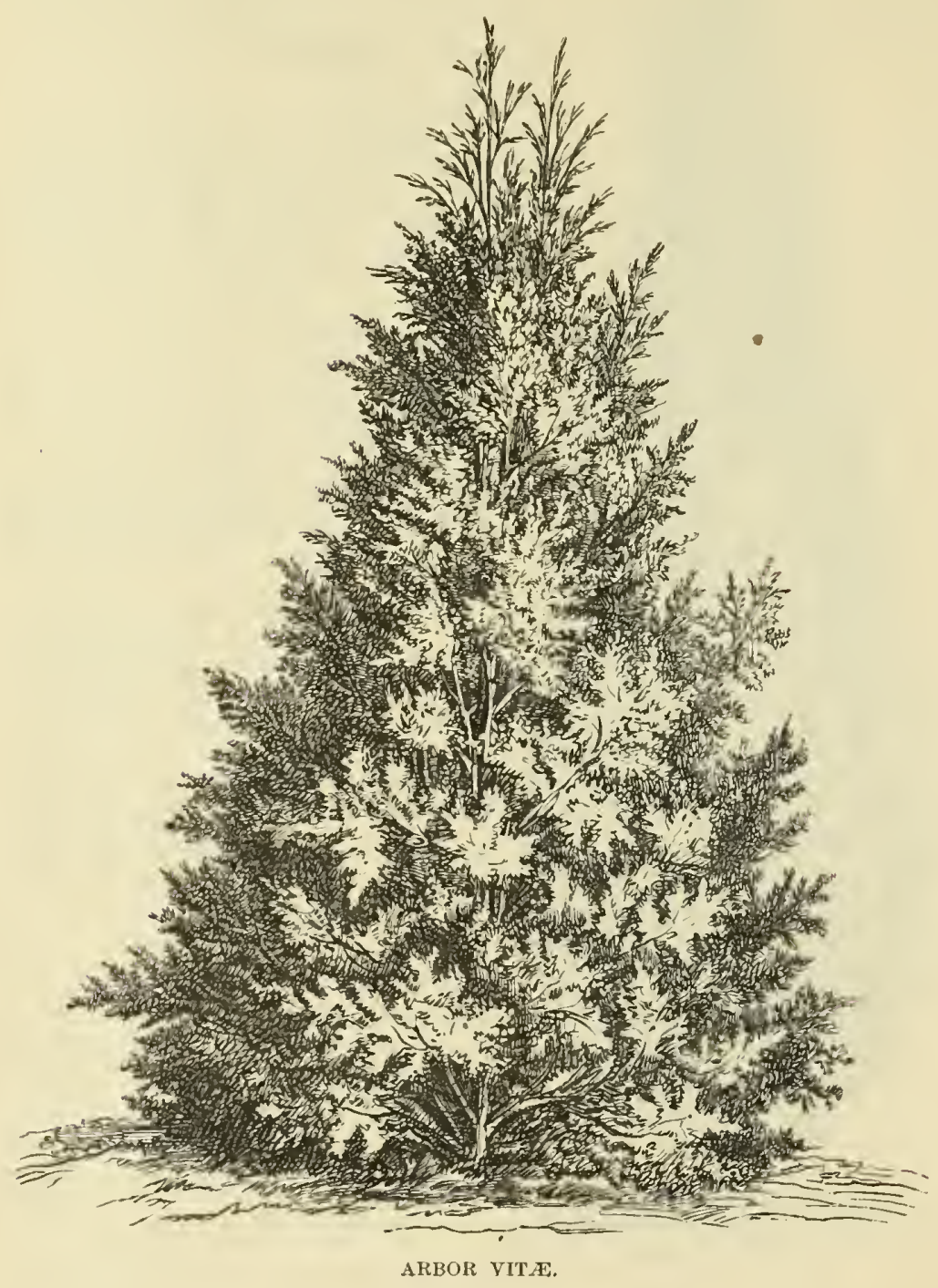




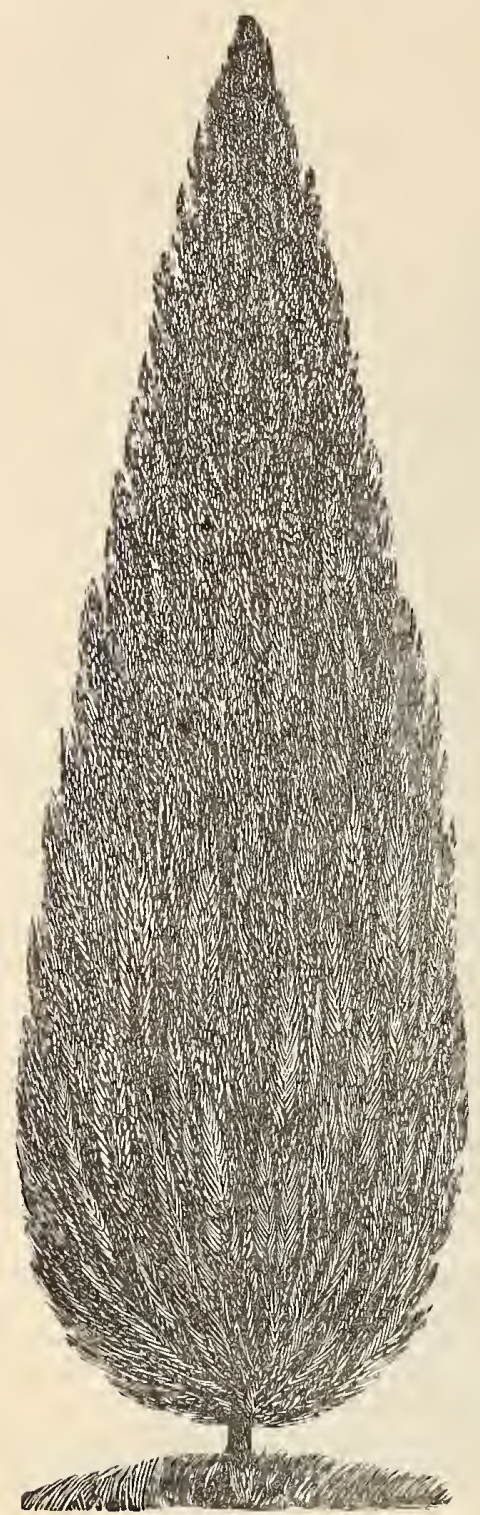

\section{ARBOR VITE. \\ Dwarf Arbor Vitæ. See Evergreen Trees.}

\section{ASHBERRY. (Muhonia.)}

Holly-Leaved. (M. aquifolia.) A most beautiful shrub, with glossy, holly-like leaves, which change to brownish green in winter; bears clusters of bright yellow flowers in May; very hardy.

\section{BOX. (Buxus.)}

Dwarf. (B. suffruticosa.) Is used for edging around flower beds.

Tree. (B. scmpervirens.) Is very ornamental as a siugle specimen on lawns, as well as for hedges.

Golden Variegated. (Bs. s. aurut. The form and growth of this is like the preceding; leaves are marked with bright yellow.

Silver Variegated. (B. s. (trgentert). This sort is of slower growth; its leaves are marked with white bands.

HOLLY. (Hex.)

American. (I. opucu.) A very handsojne, large shrub, with beautiful leaves, having small spikes on their uneven margin; flowers small, yellow. Will thrive in the shade.

JUNIPER, (J uniperus.) See Evergreen Trees.

IRISH JUNIPER.

\section{CLIMBING VINES.}

\section{AKEBIA. (Aleliar.)}

Japan. (A. quinatr,) A vine with pretty foliage, the smaller leaves resembling the clover leaf; has clusters of purplish, fragrant flowers, of singular form. 


\section{AMPELOPSIS. (Ampelopsis.)}

Virginia Creeper. (A. (minulucfolin.) A native vine of rapid growth; leaves tulu rich crinson in the fall; will cling to walls without tranung. This is of ten called the Anerican Ivy.

Veitch's Ampelopsis. (A. Veitchii.) A recent introdnction from Japan; entirely liarly: foliage turns brilliant red in the fall; small leaves, very ninch lesembling that of a maple leaf; clings tightly to walls and is handsomer than the p:cedirn: very desirable.

\section{CLEMATIS. ('lematis.)}

Coccinea. Small scarlet flowers, bell shaped.

Jackmanni. Lurge, intense violet purple; reuarkable for its velvety ricluness; frec in growth and an abundaut bloomer.

Lanuginosa Candida. Large, pearl grey, changing to white. Immense bloomer.

Viticella. Reddish violet flowers changing to blue. Larger than Flammnla but smaller than Jacknanni.

Virgin's Bower. (C. Flammulu.) Sweet scented; produces small, white flower's : very fragrant. A well known and elegant vine.

\section{HONEYSUCKLES. (Lonicera.)}

Chinese Twining. (L. J(t)mi(n)) Holds its foliage nearly all winter; bloons in July and September, and is very siveet.

Japan Evergreen. (L. Irrochl/morlu.) Is similar to the above. The leaves are more light green; retains its leaves much better than the above.

Japan Colden-Leaved. 'L. brichypodu rurere reticulute.) Beautiful toliage, sprimkled with golden spots.

\section{IVY. (Hedere.)}

English. (II. helix.) A broad leaved aud hardy sort; prefers moisture and sluate all seatson.

TRUMPET FLOWER. (Biymouiu.)

Scarlet. (I3. molimans) A splendid climber on wood or stone; vigorons and hardy, with clusters of large trumpet shaped, scallet flowers in August.

\section{WISTERIA, or CLYCINE. (Wisteriu.)}

American. (U. frutesers.) A strong grower. Flowers in short racemes of dark blue color

Chinese. (II. Sincusis.) A rapid grower, hardy; its pinkish blue flowers are pioluced in long, pendulous ricentes ; very firagrant.

\section{HEDGE PLANTS.}

l'or Evergreen ormamental hedges, the most suitable ind the most beantiful are the Hemlock Spruce, Arbor Vitix, Norway Spruce and Tree Box. Well trimmed during the first part of June, they ntake a solid compact, green wall, highly orua. mentil, around small and large yards. For screens, to conceal unsightly objects, the Hemlock, Arbor Vite and Norway Spruce are the most suitable. For shelter or wind breaks, the Norway Spruce and the Pines-White, Anstrian and Scotch,are very effective.

A defensive and very beautifnl DECrDUous hedge plant is the CYDONIA JAPONICA [Japan Quince,] flowering profusely bright red, early in spring. It makes a magnificent hedge; its compact growth with its thorns, does not allow cattle, or even chickens to penetrate it. Being uaturally a shrnb, it reqnires but little pruning ; is entirely hardy. The first cost is the only drawback it has; the after expense is but trifling.

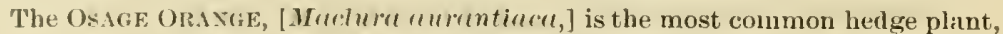
well known in the Middle and Western States; is of rapid growth, and its stout 
thorns render it very defensive ; is very cheap but also very handsome. It requires though, frequent trimming during the summer to keep it in bounds, its tendency being to form a tree. The after expense of the Osage Orange is far greater than that of the Japan Quince.

Many different kinds of shrubs, make beautiul ornamental hedges. Among them the Berberry makes a nice hedge plant, having thorns like the Gooseberry. The purple-leaved kind is highly ornamental throughout the summer. See des ${ }^{-}$ cription under "Deciduous Shrubs."

\section{ROSES.}

Persons unacquainted with the different sorts will do well to leave the selection to me but in case they name the varieties, they will please state if I may substitute others equally good, should I not be able to furnish all the sorts named. There are many kinds so near alike in color and shape that only experts can tell their differences; and in all cases I will furnish good plants of such sorts as will, in my judgment, give the purchaser entire satisfaction.

\section{CLIMBING.}

Baltimore Belle. Pale blush, nearly white; very compact; the finest of the class.

Greville, or Seven Sisters. Clusters large; Howers of various colors, from blush to crimson.

Prairie Queen. Bright rosy red, frequently with a white stripe; large, compact and globular.

Moss.

Comtesse de Murinais. (Vilwert, 18\%.) Large size, pure white.

Red.

Princess Adelaide. Fine reddish blush.

\section{HYBRID PERPETUAL.}

American Beauty. Large, deep pink shaded with carmine; delicious odor.

Anna de Diesbach. Large; bright rose.

Beauty of Waltham. Large and full; cherry, changing to bright rosy carmine; very fragrant and a good bloomer.

Belle de Normandie. Beautiful, clear rose; large. center.

Caroline de Sansal. Large, full, pale flesh color, deepening towards the

Duke of Edinburgh. Dark velvety maroon, medium size.

Duke of Wellington. (Granger, 1864.) Bright red and velvety.

Enfant de Mt. Carmel. Brilliant rosy carnine; very large.

Francois Levet. I Large, rose color ; resembles Paul Neyron.

General Jacqueminot. Brillant beautiful crimson.

Glory Lyonaise. White, tinted yellow, large and moderately full.

Her Majesty. Clear and bright satiny rose; exceedingly large, very full and symmetrical.

John Hopper. Bright rose, with carmine center; large and full.

Jules Margottin. Brilliant crimson; large and full.

La Reine. Rosy pink; large and double; good grower.

Louis Van Houtte. Rich, velvety crimson; deliciously perfumed.

Mad. Plantier. Pure white; large and double.

Madame Trotter. Bright red; large and full; good grower and bloomer.

Madame Victor Verdier. Brilliant carmine crimson; large and full.

Madame Charles Wood. Large, brilliant red, passing to lively rose.

Mademoiselle Marie Rady. Bright red, shaded with crimson; large. 
Magna Charta. Bright pink; very large, full, free bloomel and strong grewerl.

Marechal Vailliant. liosy crimson; large aud double.

Miss Hassard. A beuntiful pink rose of fine form and habit.

Paul de Neyron. Ie(2) rose; free blommer; vigorous, desiralle.

Prince Camille de Rohan. l)ep velvety trimson; large.

Souvenir of the Queen of England. 13right caruline, large and fine.

TEA, BOURBON, NOISETTE AND BENGAL ROSES.

These are very frec bloomers, but they require protection duling the winter.

Appoline. Delicate pink; large.

Agrippina. Brilliant fiery red; profuse hloomer.

Bon Silene. Rose color; free blonmer.

Cloth of Gold, or Chromatella. Petals golden yellow, with sulplur edges, Very beantiful, but a slyy bloomer.

Duchess of Edinburg. An elegant crimson lud, of gool size and fine form. A new eolor among teas.

Hermosa. Clear rose; constant bloomer.

Isabella Sprunt. Sulplur yellow; beautiful buds, profuse bloomer.

La Pactole. Pale sulphur yellow; very sweet.

Levison Cower. large and very double. Salmon and rose.

Lucullus. Deep crimson maroon, good grower and free bloomer.

Madame Damazin. Salmon color; free blooner.

Madame Falcot. Saffron yellow.

Marechal Neil. Deep golden yellow; large, full and fragrant.

Marie Guillot. White, tinted with pale yellow; large and full.

Safrano. Yellowislı buff; prorluces fine burls.

Solfaterre. Sulphur yellow; large, double and fragrant.

Sir Walter Scott. Briglit rose; profuse blonu. 


